\title{
16
}

\section{Colonisation and culture change in the early prehistory of Fiji}

\author{
Geoffrey Clark \\ Department of Archaeology and Natural History, The Australian National University \\ Atholl Anderson \\ Department of Archaeology and Natural History, The Australian National University
}

\section{Introduction}

The arrival of humans in the Fiji Islands at ca. 2950-3050 cal. BP was, in historical and ecological terms, a momentous event in Pacific prehistory that nonetheless comprised only a relatively small part of the Lapita expansion in Near and Remote Oceania. In turn, Lapita colonisation was only one of several prehistoric migratory movements in Oceania that began during the late Pleistocene movement to Near Oceania (Allen and O'Connell 2008), with the frequency and scale of maritime movements increasing during the late Holocene (Anderson 2001; Green 2003). In this chapter, we situate the colonisation of Fiji and the Early Prehistory of Fiji Project results in the Lapita expansion, contrasting it with human arrival in western Micronesia and the colonisation of East Polynesia. These prehistoric migratory movements suggest a preference for colonisation of uninhabited landmasses. In the case of Lapita migration, suspected avoidance of the main Solomon Islands and Samoa raises, among other critical issues, questions about seafaring capacity and colonisation pattern during the Lapita era. These are particularly important when considering human arrival in Fiji-West Polynesia because the $800+\mathrm{km}$ water gap separating Vanuatu-New Caledonia from Fiji was the largest inter-archipelagic voyage in the Lapita world, and it is generally held to be a significant barrier to Lapita movement (Green 1991; Irwin 1992; Clark and Murray 2006).

A seafaring ability that was able to bypass extensive island groups like the Solomons and Fiji (Burley and Dickinson 2001; Sheppard and Walter 2006) alludes to a maritime capacity with 
the potential to transport large migrant numbers to Fiji from several western archipelagos settled by Lapita groups. However, the evidence for systematic long-range voyaging in Remote Oceania is equivocal (Anderson 2003, 2008a; Irwin 2008), and a predominantly incremental pattern of movement is suggested by the distribution of Kutau/Bao obsidian and the localisation of ceramic designs, notwithstanding the likelihood that some long-range passages occurred in Lapita times. At the intra-archipelagic level, the Lapita dispersal in Fiji is examined using stylistic variation among early ceramic assemblages, site characteristics and the subsistence economy. The postLapita period, starting at ca. $2500 \mathrm{BP}$, is argued to represent a significant shift in settlement approach, landscape use, and mobility patterns, which, by the first millennium AD, contributed to the increased diversity of human systems in Fiji.

\section{Lapita colonisation and oceanic migration}

The late-Holocene migration of people in the Pacific Ocean took in three distinct geographic areas that in orthodox scholarship represent independent dispersal events during the period ca. $3500 \mathrm{BP}$ to $700 \mathrm{BP}$ (Figure 170).

The smallest and possibly oldest dispersal was to western Micronesia. It probably originated from eastern Indonesia-southern Philippines (Callaghan and Fitzpatrick 2009) and encompassed Palau and the Mariana Islands, with indirect evidence that it also included Yap (Donaldson and Intoh 1999). The dating of this expansion is uncertain, with archaeological sites in Palau and Saipan dating no older than 3500-3100 cal. BP (Clark 2005; Liston 2005; Clark et al. 2006; Carson 2008), but palaeoecological data that might indicate human activity as early as $4500 \mathrm{cal}$. BP (Athens et. al 2004; Dickinson and Athens 2007). Archaeological dates on marine bivalves extend to 3100-3000 cal. BP on Palau and to $3500 \mathrm{cal}$. BP on Saipan (Carson 2008), but the latter determinations are probably affected by burning and are too old. If so, western Micronesia was probably settled at 3400-3200 cal. BP, although a robust colonisation chronology for the region has yet to be established (Clark 2004).

The second dispersal was the Lapita migration, which extends from Manus in the west $\left(146^{\circ} 57^{\prime}\right)$ to Samoa in the east $\left(172^{\circ} 03^{\prime}\right)$. It has been considered a separate event from the colonisation of western Micronesia, although both have a similar antiquity of ca. 3400-3000 cal. BP based on radiocarbon dates from archaeological sites (Clark 2005; Specht 2007; Green et al. 2008), and both involved groups that derived ultimately from Island Southeast Asia and produced various types of red-slipped pottery. A direct connection between the two migrations has been proposed (Craib 1999), and Bellwood (2005) suggests a direct origin for Lapita culture in the Mariana Islands of western Micronesia. Accepting the generic similarities in material culture, there are, however, also significant differences in the two cultural assemblages, including an absence of pig, dog and Rattus exulans remains in western Micronesia before about 2000 BP (Anderson 2008b). Analysis of modern pig DNA suggests that the western Micronesian source is East Asian, while pigs in Melanesia and Polynesia belonged to a Pacific clade (Larson et al. 2007). There are also dissimilarities in pottery and shell ornaments (Szabo and Summerhayes 2002; Carson 2008; DeFant 2008).

The third migration was of Polynesians from the Tonga-Samoa region eastward to the Cook Islands, Society Islands and Marquesas. The chronology of this expansion is debated, with current radiocarbon dates for migration at 1200-800 BP (Anderson and Sinoto 2002; Green and Weisler 2002; Conte and Anderson 2003). This movement, possibly divided into earlier tropical and later sub-tropical to temperate-zone migrations, eventually encompassed New Zealand, Easter Island and Hawaii (Hunt and Lipo 2008; Wilmshurst et al. 2008), along with numerous islands and atolls within triangle Polynesia, including some that were abandoned in 


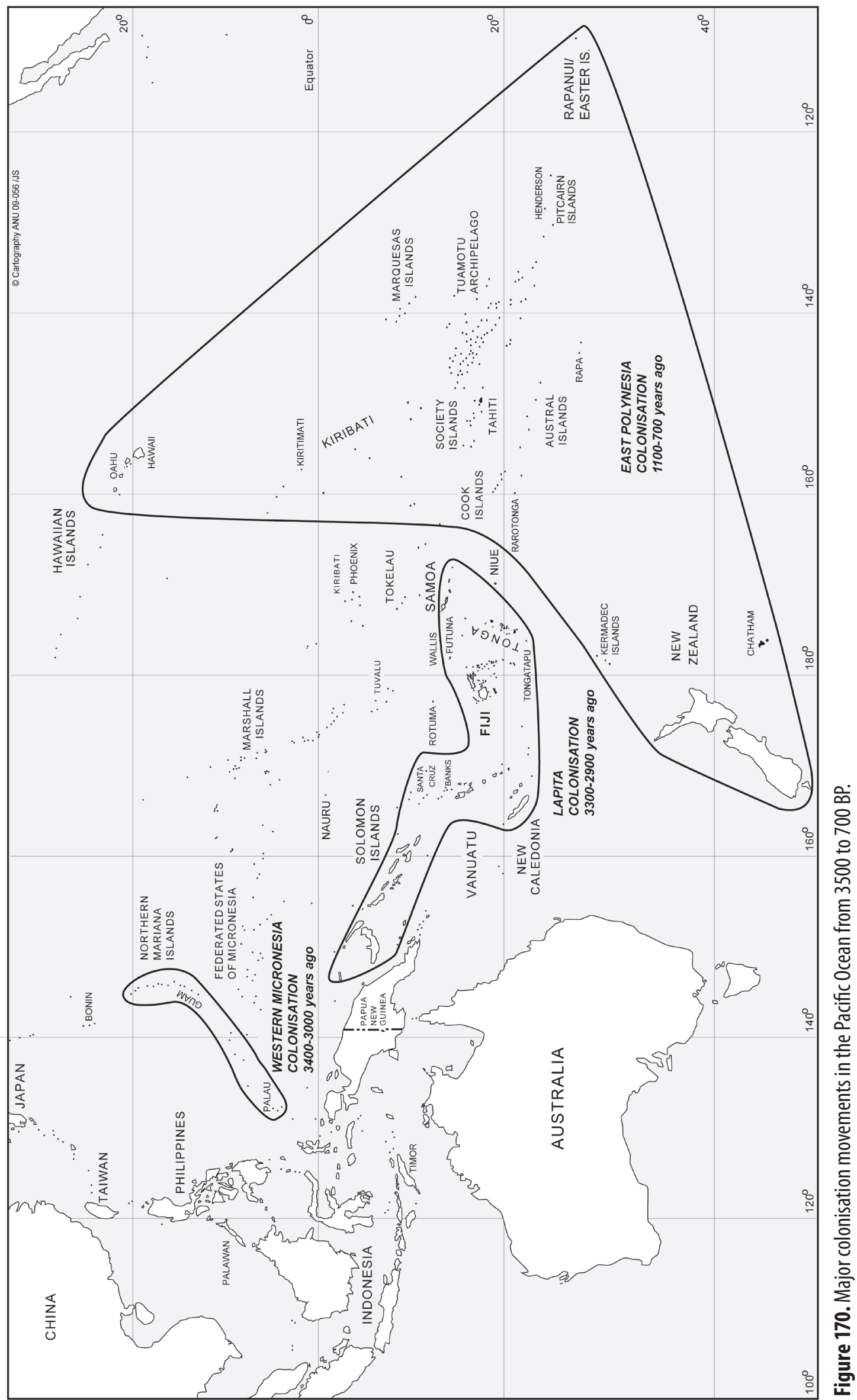


prehistory (Weisler 1994; Anderson and White 2001; Anderson 2002).

Whatever the proximate cause(s) of migration in Remote Oceania (Anderson et al. 2006a), it is useful to compare dispersal among the regions. Dispersal to western Micronesia occurred over a distance of $2300 \mathrm{~km}$ and took in between $9^{\circ}$ and $13^{\circ}$ of latitude (north), depending on an origin in eastern Indonesia or the southern Philippines. Lapita dispersal extended $4680 \mathrm{~km}$ and took in $21^{\circ}$ of latitude (south). The East Polynesian language-culture distribution spans some $7400 \mathrm{~km}$ and a staggering $68^{\circ}$ of latitude. As the periods involved are a few hundred years in each case, the rate of dispersal was increasing (cf. Irwin 1992). Anderson (2001) suggests this was also happening within the Lapita expansion. Whether the rates reflect changes in dispersal capability, for example in seafaring technology, or in some other variables, is open to conjecture. The wind conditions for eastward travel are less favourable in Micronesia and East Polynesia than in the Lapita region, where monsoonal westerlies are relatively predictable and seasonally persistent. The ability to move a large colonising propagule, which is partly a function of proximity between source and destination, would affect the demography of colonisation and it may be, for example, that many fewer people reached western Micronesia than Santa Cruz in the Lapita era and that their ability to sustain continuing migration was attenuated accordingly. Again, it might be a function of incentive. There is not much beyond western Micronesia, but beyond Santa Cruz there are many large islands. It may have been for the latter reason that west Micronesian expansion captured only 1600 sq. km of land, compared with a Lapita expansion across 146,000 sq. $\mathrm{km}$ of land. East Polynesian migration captured 288,520 sq. km, although this cannot have been by land-area incentive, which declined eastward, the discovery of New Zealand being entirely unpredictable and representing more than $90 \%$ of the East Polynesian land area.

If migration success is measured by the proportion of land area to dispersal area, the capture rate of land, then this gives an index of migration success (MI), which has western Micronesia with an MI of 0.08, East Polynesia with an MI of 0.48 and Lapita colonisation with the highest MI of 1.5 (Figure 171). Using ocean area (sq. km) for the three expansions produces the same pattern (Figure 171), indicating that Lapita migration might be considered the most successful of the three movements in terms of locating and colonising island territory. The migration index values could also suggest that because Lapita colonisation was supported by high territory yields relative to the costs and risks of dispersal, the migration stream may have been continuous, especially in the region from the Bismarck Archipelago area to the Vanuatu-New Caledonia area, where the size of islands/archipelagos is relatively large, island inter-visibility is high and intervening water gaps are $350 \mathrm{~km}$ or less.

The early movements in Remote Oceania thus show a contrast in dispersal versus land capture. West Micronesia was low on both counts, East Polynesia had high dispersal but relatively low capture - and it would be exceedingly low if New Zealand had not been found (see Figure 171), while Lapita has moderate dispersal and high land capture.

\section{Colonisation movements and inhabited landscapes}

How population movements were constrained or absorbed by the presence of already-inhabited islands is an important consideration in migration studies, and has implications for Lapita expansion and the colonisation of Fiji. In the case of Polynesian expansion, the prevailing approach was to discover and occupy uninhabited and remote islands in the eastern Pacific, even though large but already populated archipelagos such as Fiji, Vanuatu and New Caledonia lying to the west of Samoa-Tonga could have been reached, particularly from Tonga, using the prevailing southeast trade winds. Indeed, there are Polynesian settlements to the west of Tonga-Samoa 


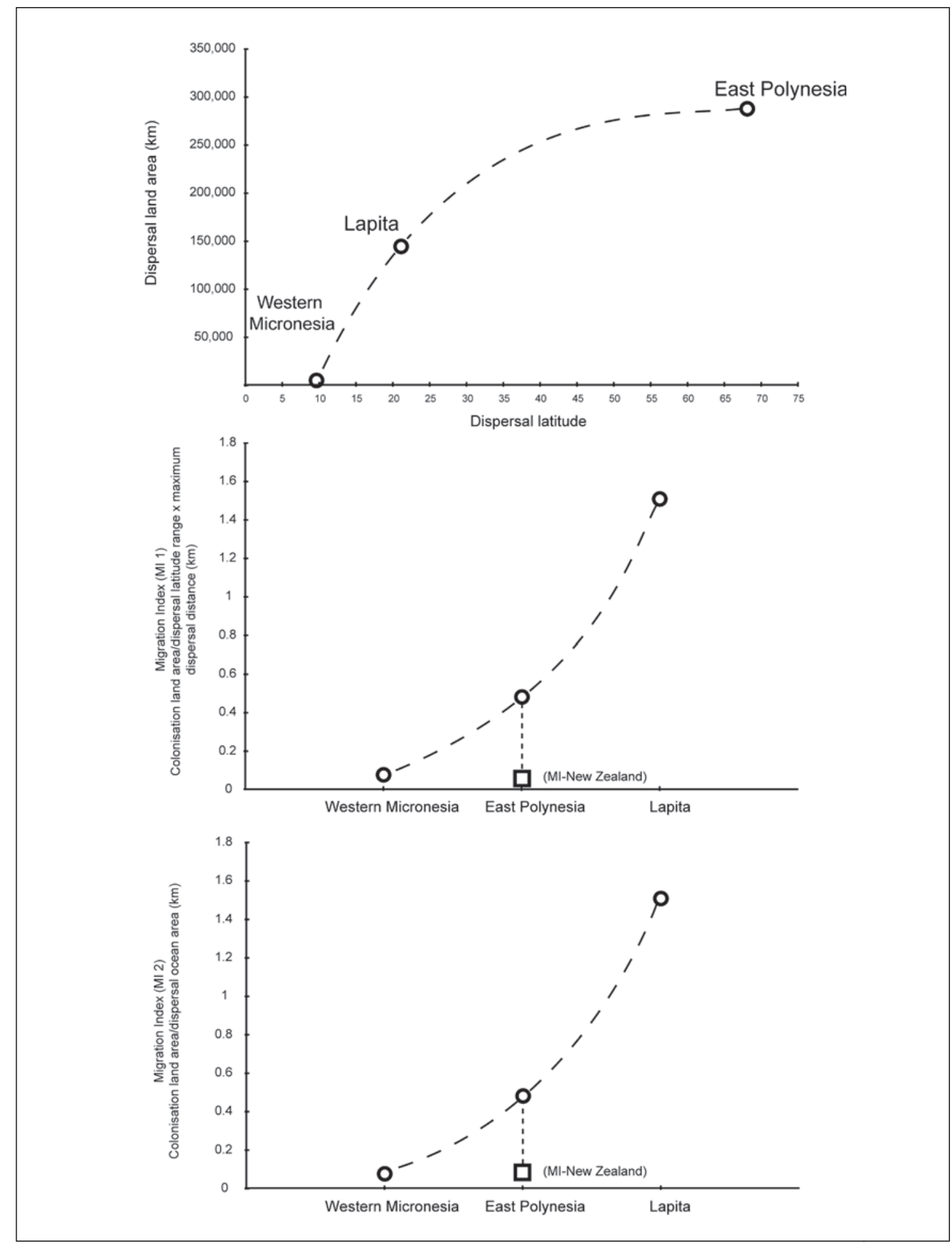

Figure 171. Comparative views of three prehistoric migration events. Top, island land area colonised versus dispersal latitude range. Middle and bottom, migration index values for three colonisation events calculated by dividing the land area colonised in each event by dispersal area (MI 1=latitude range $\mathrm{x}$ maximum dispersal distance, $\mathrm{MI} 2=$ dispersal ocean area). Western Micronesia may have been colonised by separate colonisation movements, but it is included as an entity because the expansion(s) appears to have originated from Island Southeast Asia at approximately the same time (3300-3000 cal. BP). For East Polynesia, two Ml values were calculated. The first (circle symbol) is based on the prehistoric culture distribution, while the second (square symbol) is the index value after removal of New Zealand's land area, which comprises more than $90 \%$ of the colonised land in East Polynesia. Note that Lapita colonisation was the most successful of the three movements in terms of land capture. 
known as the Polynesian Outliers (Kirch 1984b), yet almost all are isolated or in peripheral positions adjacent to larger islands, and most are atolls or raised coral (makatea) environments that are relatively poor in terrestrial resources. The marginal tendency of Outlier geography might result from resistance to colony emplacement on large volcanic/island arc islands that were already supporting large established populations.

Linguistic subgrouping based on shared innovations places the Polynesian Outliers in Nuclear Polynesian (Northern Pre-Polynesian) and separating before the formation of Eastern Polynesian (Marck 2000; Kirch and Green 2001). Eastern Polynesian can be archaeologically dated to about 1200-1000 BP (Anderson and Sinoto 2002; Anderson 2003; Conte and Anderson 2003; Hunt and Lipo 2008). If occupation of the Outliers was not the result of involuntary voyages, and the linguistic sequence is accurate and not skewed by variation in the rate of lexicon replacement and borrowing, then there may have been an earlier phase of Polynesian voyaging westward, presumably at a time before the Society Islands and other uninhabited islands were discovered to the east. Although Polynesians may have reached Australia and South America (Storey et al. 2007; cf. Gongora et al. 2008), no definitive evidence for a prehistoric settlement has yet been reported on either continent. The western limit of Polynesian colonisation (excluding sites in southern New Zealand) is currently the Emily Bay site on Norfolk Island (Anderson and White 2001), some $1400 \mathrm{~km}$ from Australia, and the eastern limit of Polynesian settlement remains Easter Island/Rapa Nui.

The dominant pattern of avoidance of already inhabited landmasses needs to be considered in relation to Lapita colonisation, which clearly failed to reach or avoided Australia and New Guinea, and which, judging by the location of many Lapita sites on offshore islands, may have been relatively unsuccessful initially on large islands such as New Britain and New Ireland (Spriggs 1995; Specht 2007:56). Torrence and Swadling (2008) propose that mid-Holocene social networks in New Guinea and surrounding islands, marked by the distribution of stemmed obsidian stone tools and stone mortars and pestles, could have encouraged the uptake and spread of Lapita material culture among indigenous groups - an idea that can be examined from the discovery of non-Austronesian sites that are contemporary with Lapita settlements in Island New Guinea. The existence of complex interaction networks involving what are likely to be prestige items in New Guinea-Island New Guinea implies the presence of stable social groups, which, alternatively, might have resisted migrant entry, or at least resisted the material culture of migrants. One possible indication of this is the inland distribution of 'bird and wing' mortars in New Guinea where Lapita pottery has yet to be recorded (Torrence and Swadling 2008).

The almost complete absence of knowledge about the nature of Lapita and non-Lapita interaction anywhere in the Bismarck Archipelago means that we cannot yet evaluate the effects of migrant-indigenous interaction in relation to Lapita colonisation (but see Lilley 2002; Pawley 2007, n.d.), which might also have been influenced by the Witori W-K2 eruption on New Britain at 3500 BP (Torrence and Doelman 2007) and the prevalence of malaria in the region (Groube 1996). Nonetheless, an apparent preference for uninhabited islands seen in Polynesian colonisation and the admittedly slender evidence for limited engagement in the Bismarck Archipelago could suggest that the location of early Lapita colonies was influenced by the presence of indigenous populations in Near Oceania.

\section{Archipelago avoidance by Lapita migrants?}

A view that Lapita migrants avoided occupied island groups has recently been put forward in relation to the main Solomon Islands. The northern islands in the Solomons were first occupied in the Pleistocene by non-Austronesians, judging by dates of 20-28 ka at Kilu Cave on Buka, although prehistoric sites older than $6000 \mathrm{BP}$ have yet to be found further south even though 
the Buka-Guadalcanal landmasses were of much greater size during periods of low sea level (Spriggs 1997; Chappell 2005). Sheppard and Walter (2006:48) suggest that the absence of early Lapita sites in the main Solomons suggests these islands were entirely leap-frogged, with migrants travelling directly from Island New Guinea to the Reef/Santa Cruz Islands.

Such a leap-frogging pattern of movement of early Lapita colonists is thought to be the result of negative and positive factors. On the one hand, an already established population in the main Solomon Islands inhibited early Lapita occupation, and on the other, the discovery that uninhabited islands east of the main Solomons held dense and easily accessible marine and terrestrial resources encouraged long-distance movement and avoidance of the main Solomons. While there are linguistic and archaeological critiques of the idea (Felgate 2007; Clark and Bedford 2008; Pawley n.d.), including the fact that substantial quantities of chert found in early Lapita sites in the Reef/Santa Cruz Islands originate from Ulawa/south Malaita $400 \mathrm{~km}$ away in the central Solomons (Sheppard 2003), it remains a valid hypothesis (e.g. Lilley 2008).

The possible avoidance of the main Solomon Islands is also significant for ideas about Lapita seafaring and colonisation patterns once the previously uninhabited island groups east of the Reef/Santa Cruz Islands had been discovered. To reach Vanuatu and New Caledonia from the Reef/Santa Cruz Islands requires voyaging south over a total of 10 degrees of latitude, although no inter-island distance is greater than $250 \mathrm{~km}$. However, if the main Solomon Islands were avoided by Lapita colonists, and extensive contact between the Bismarck Archipelago and the Reef/Santa Cruz Islands was maintained, as the volume of Talasea obsidian in the RF-2 site suggests (Sheppard 2003), then canoe voyages of more than $800 \mathrm{~km}$ might have been routinely undertaken during Lapita expansion to Remote Oceania.

There are significant implications of this for the colonisation of the Fiji Group and West Polynesia because the ocean gap of $800 \mathrm{~km}$ separating Fiji from southern Vanuatu has long been seen as a barrier that reduced the volume and frequency of Lapita migration (Green 1991; Irwin 1992). Further, once in the Fiji Group, voyages of $370 \mathrm{~km}$ were needed to reach Tongatapu, and voyages of 500-700 km to reach Samoa. One indication that Lapita voyaging thresholds were being approached in Fiji-West Polynesia might be the fact that small and relatively remote islands like Rotuma, $470 \mathrm{~km}$ from Fiji, and Niue, $410 \mathrm{~km}$ from Tonga (Vava'u), do not appear to have been settled in Lapita times (Walter and Anderson 2002), or indeed 'Ata, fewer than $100 \mathrm{~km}$ south of Tongatapu. If uninhabited island groups were perceived as being of high value to oceanic migrants and were the main target of dispersal, then the discovery of Fiji-West Polynesia, with a combined land area of some 22,100 sq. $\mathrm{km}$, could well have stimulated a major phase of migration, especially if accurate voyages of $800 \mathrm{~km}$ were within the capacity of Neolithic seafarers.

However, measured by numbers of sites with dentate ceramics, the Lapita occupation of Fiji-West Polynesia exhibits significant patchiness indicative of a migration movement that was slowing. In northern Tonga and Samoa, the number of recorded Lapita sites is much fewer than in southern Tonga. For northern Tonga, across the 71 islands of Vava'u only five Lapita sites have been identified, all small and covering no more than 1500 sq. m each (Burley 2007). The number is in striking contrast to central and particularly southern Tonga, where the density of ceramic sites suggests rapid population expansion during Lapita and post-Lapita phases (Burley et al. 2001; Burley 2007). The western end of 'Upolu has a single Lapita site, Mulifanua, which is submerged from flexural subsidence of the lithosphere under volcanic loading (Dickinson and Green 1998). Radiocarbon dates from archaeological sites in Samoa and American Samoa when filtered through 'chronometric hygiene' protocols suggest that permanent settlement of Samoa did not take place until 2500-2400 BP (Reith et al. 2008). 
Natural and anthropogenic factors have transformed the landscape of the Samoan Islands (J. Clark 1996; Green 2002; Reith et al. 2008) to a greater extent than Fiji-Tonga, but despite this, Addison and Morrison (In press) and (Reith et al. 2008) believe that the radiocarbon record demonstrates the failure of Lapita colonisation in Samoa. Unlike the main Solomon Islands 'gap', the Lapita avoidance of Samoa cannot result from the restrictive effects of an already resident population, or from the size of inter-archipelagic distances if voyages of $800 \mathrm{~km}$ were commonly undertaken. Demographic exhaustion is a potential explanation if Lapita populations were concentrated in the Fiji Islands, either because of a preference for large continental islands or because migrant numbers were low and contained by the extensive coastlines of Viti Levu and Vanua Levu.

Different patterns of archipelago colonisation are suggested for Tonga, where the Nukuleka site on Tongatapu Island has tan-paste ceramics, some of which have a quartz-pyroxene temper indistinguishable from temper in a non-local sherd from a Lapita site on Nendo in the Reef/Santa Cruz Islands. The source of this distinctive temper must lie west of Tonga, and while a source in Fiji cannot be excluded, the presence of subordinate hornblende in the exotic sherds suggests an origin in Vanuatu (Dickinson 2006). Of the numerous alternatives suggested by the presence of the tan-paste sherds in Tonga, Burley and Dickinson (2001) propose direct settlement of southern Tonga by a Lapita group that bypassed the Fiji Islands, signalling a canoe voyage of $1750 \mathrm{~km}$ (central Vanuatu-Tongatapu) or $2300 \mathrm{~km}$ (Nendo/Santa Cruz-Tongatapu).

This idea is initially attractive when considered together with an apparent Lapita avoidance of northern Tonga and Samoa, as it suggests that the founding population of Tonga was small and perhaps unable or unwilling to expand initially northward beyond the Haapai Group. Second, disparate colonisation movements from different parts of the migration stream are a plausible explanation for the physical differences observed today between the populations of Fiji and Tonga-Samoa, glossed as the 'Melanesia-Polynesia' divide (Clark 2003). These differences are elsewhere held to have developed in the post-Lapita period (e.g. Burley 2005; Cochrane 2008), but Donohue and Denham (2008) suggest that Lapita migration included 'Asiatic' Austronesian and 'Papuan' non-Austronesian components, either as separate population strata or in a migration stream that combined the two.

Yet, while it is an intriguing proposition, a Lapita canoe voyaging range of $1700-2300 \mathrm{~km}$ is not otherwise well attested, except for a potential late-Lapita/post-Lapita presence in Australia that might derive from the Solomon Islands and/or New Guinea (Felgate and Dickinson 2001; Felgate 2007), and colonisation movements to western Micronesia. Open ocean voyages of such magnitude are uncommon until Polynesian expansion some 1800 years later, and if such distances were a feature of Lapita seafaring, you would expect that at least some parts of East Polynesia would have been colonised earlier. The prospect of a Lapita migration stream containing groups with different physical characteristics that resulted ultimately in the Polynesia-Melanesia divide is feasible, although it raises the uncomfortable prospect that inter-group biological variability among Lapita groups has been concealed in the archaeological record by the material-culture similarities of Lapita ceramics, ornaments and adzes.

The proposed Lapita avoidance of Samoa, either through demographic exhaustion or a west Fiji colonisation pattern that was different from the Lapita colonisation of east FijiTonga-Samoa, has two logical deficiencies. The first is that several islands near to Samoa have prehistoric records that begin in Lapita times and indicate occupation thereafter. The second is that the post-Lapita ceramic record of Samoa does not currently have a close relationship with any other assemblage in the region, even though Samoa is argued to have been permanently occupied by pottery-making people who settled there at 2500-2400 BP. 
The small island of Futuna, some $560 \mathrm{~km}$ from Samoa, has four Lapita sites (Sand 1990:125) and Uvea, $360 \mathrm{~km}$ from Samoa, has at least three sites with dentate-stamped ceramics (Frimagacci and Siorat 1983; Sand 1996). Niuatoputapu is only $280 \mathrm{~km}$ from Samoa and has one Lapita site (Kirch 1988), but Futuna, Uvea and Niuatoputapu have post-Lapita deposits with plainware ceramics and radiocarbon dates indicating continuous occupation since the Lapita era. Further, design motifs and elements from the NT-90 site on Niuatoputapu analysed by Kirch (1988) showed close relationships between Lapita sites in Fiji-West Polynesia (Sigatoka-Uvea 0.90, Mulifanua-Niuatoputapu 0.91, Niuatoputapu-Uvea 0.93), suggesting a degree of inter-island mobility and contact towards the end of the Lapita period when Samoa is suggested to have been abandoned (Reith et al. 2008).

The mobility indicated by the ceramic data is reinforced by archaeological evidence for Lapita movement in Fiji-West Polynesia. Obsidian from Lapita deposits in Lakeba has been sourced to northern Tonga (Best 1984:434; Reepmeyer and Clark 2009), and the same material has been recorded from a late-Lapita site in southern Tonga, while a quartz-bearing sherd from the Mulifanua site in Samoa most likely derives from Vanua Levu in Fiji (Dickinson 2006:118). It does not seem probable that highly mobile colonising groups would settle small islands close to Samoa, but fail to occupy the large islands of the Samoa Group for 400 years (Clark and Bedford 2008).

Another objection concerns the nature of Samoan ceramic assemblages. Post-Lapita pottery from west Fiji and the Lau Group, as well as from southern Tonga, Futuna, Uvea and Niuatoputapu, is different from the exclusively plainware-bowl assemblage in Samoa dating to at least 2400-1700 BP. Since the Samoan plainwares cannot be derived convincingly from known prehistoric assemblages in the region (or from Vanuatu and New Caledonia), they are likely to represent a local development, signalling that older ceramic sites are likely to be present in Samoa. Notwithstanding the results of radiocarbon-date reviews and GIS modelling (Reith et al. 2008; Addison and Morrison In press), we suggest that ceramic assemblages from Fiji-West Polynesia do not support a hypothesis that Samoa was re-settled at 2500-2400 BP.

An underlying problem in this discussion is whether patterns of voyaging are discerned adequately from ceramic data. Migration voyaging, whether in exploratory or colonising mode, probably carried little pottery and conserved what it had, in the expectation that cooking could be carried out by alternative means during short stops along the way and that new pots would be made immediately on arrival; which, in the latter case, is what sourcing studies generally suggest to have been the case. Therefore, while the distribution of pottery in any quantity indicates places where people settled, its absence elsewhere does not necessarily show that those places were avoided as temporary landfalls, brief encampments and so on, the evidence for which is very much harder to find or recognise, yet might well exist along the coasts of the Solomons and Fiji. In short, to read absence of pottery as evidence of very long-distance passages accomplished without stopping is quite probably inaccurate both in terms of sailing capability and migration behaviour.

\section{Incremental colonisation and Kutau/Bao obsidian}

If archipelago 'avoidance' models and long-distance 'point-and-arrow' migration movements (Burley and Dickinson 2001; Sheppard and Walter 2006; Lilley 2008) are not convincingly supported, as we argue in relation to Samoa, then it is necessary to ask whether there is archaeological data consistent with incremental movement, recognising that oceanic expansions may have involved elements of both gradual and punctuated movement.

Comparison of ceramic motifs in Lapita sites is a valuable method for tracking Lapita 
movement at the archipelagic scale, but there is uncertainty about the processes of decorative change, with researchers interpreting the stylistic data as evidence for ongoing interaction across the Lapita range, or, alternatively, rapid localisation of ceramic assemblages (Sand 2001; Summerhayes 2001; Clark and Murray 2006).

Instead, we examine the distribution of obsidian from the Kutau/Bao source in west New Britain, which was the most widely distributed material in Lapita times, although it was not always the most abundant obsidian in a number of West Pacific Lapita sites (Spriggs 1991; Wickler 2001; Specht 2002; Summerhayes 2004). Models of obsidian use suggest it was employed and discarded in a utilitarian manner, with the procurement of Kutau/Bao obsidian representing the importance of ongoing social connections among Lapita groups, particularly those in the Reef/Santa Cruz Islands (Sheppard 2003; Specht 2002).

If obsidian transfer from west New Britain was essentially a byproduct of Lapita social connectivity, then variation in the quantity of obsidian across the Lapita range should reflect elements of the broader dispersal pattern. For instance, a Lapita movement that was predominantly incremental should be manifested by a typical down-the-line distribution characterised by high obsidian frequencies around the source, low-to-absent frequencies at the migration terminus, and intermediate amounts of obsidian in between. Alternatively, long-distance voyaging and archipelago avoidance would leave a different obsidian footprint, as movements originating from locations with abundant Kutau/Bao obsidian, like the Reef/Santa Cruz Islands, should have significantly more obsidian than Lapita movements originating from locations where there was little. In brief, incremental archipelago movement should be characterised by obsidian amounts that decrease monotonically with distance from source, while an expected feature of 'point-and-arrow' movement is an obsidian distribution where there is no linear relationship between obsidian abundance and distance from source.

The high proportion and volume of Kutau/Bao obsidian in several Reef/Santa Cruz sites supports the maintenance of social relations among Lapita groups separated from each other by the main Solomon Islands (Sheppard 2003; Sheppard and Walter 2006). In Remote Oceania, the amount of Kutau/Bao obsidian declines rapidly with distance from the Reef/Santa Cruz Islands (Figure 172), consistent with a predominantly incremental pattern of colonisation, as several other researchers have also argued (Sand and Sheppard 2000; Reepmeyer et al. In press). Since the Reef/Santa Cruz sites have significant amounts of Kutau/Bao obsidian, but are around $2000 \mathrm{~km}$ from the source, it appears that Lapita migration in Near Oceania was very different than in most of Remote Oceania. Lapita settlements might have involved higher rates of community interaction throughout the Bismarcks-Reef/Santa Cruz region, compared with rapid dispersal and post-colonisation fragmentation of social networks beyond the Reef/ Santa Cruz Islands (Green and Kirch 1997; Anderson 2001). Thus, the Reef/Santa Cruz Islands appear to have been an important colonisation node or 'gateway' to Remote Oceania, through which the migration stream funnelled when the existence of the large and uninhabited island groups of Vanuatu and New Caledonia became known to Lapita communities.

\section{Lapita colonisation of the Fiji Islands}

Lapita groups occupied the varied landscapes of Fiji probably as a result of numerous factors, including migrant numbers, maritime capacity, subsistence economy, physical geography and the nature of migrant social systems, few of which can be estimated accurately with existing archaeological information. In its stead and acknowledging the deficiencies in our data sets, we review the Lapita settlement of Fiji using radiocarbon dates and inter-site ceramic variation to examine the colonisation pattern, before outlining the site characteristics and evidence for 


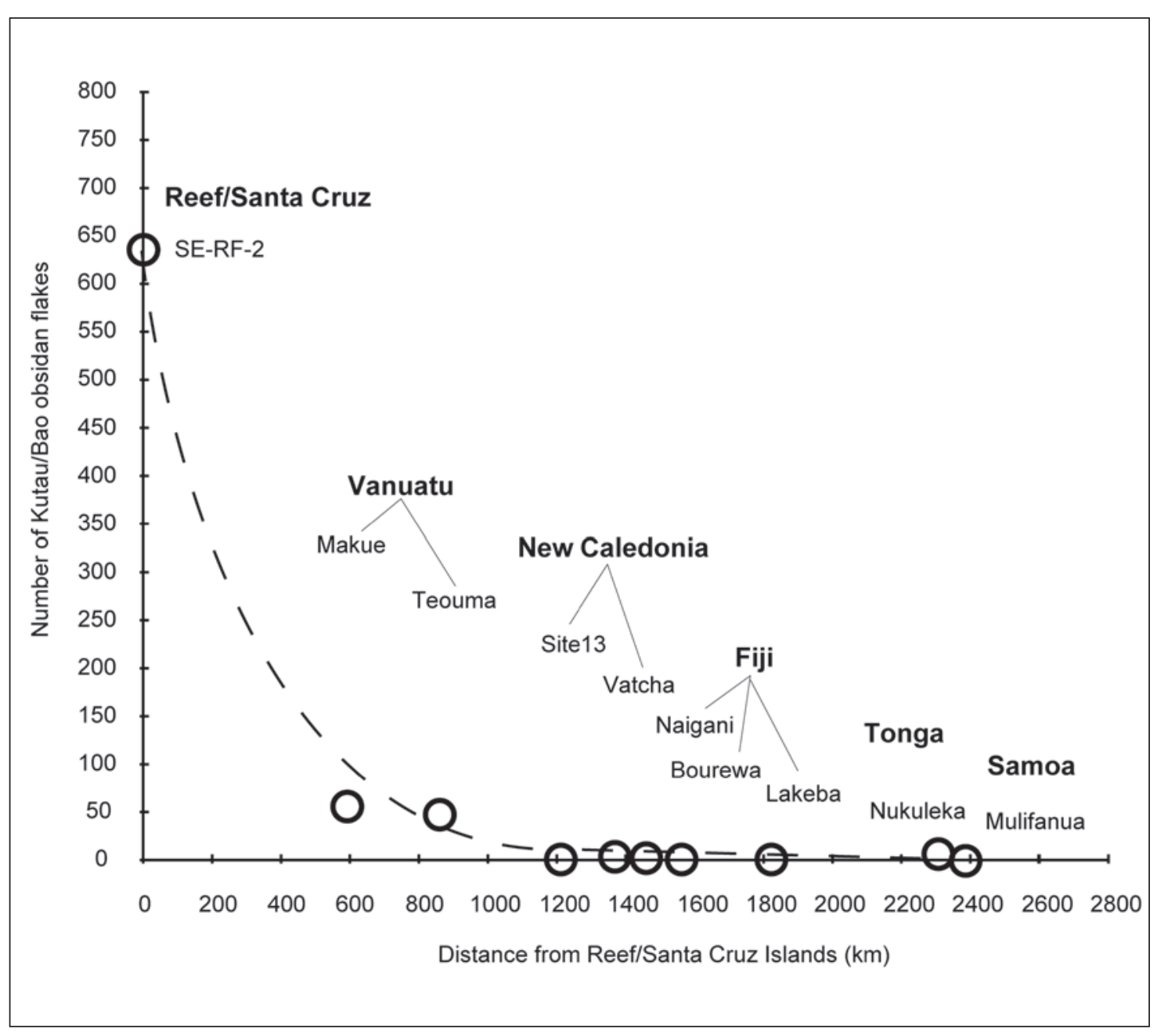

Figure 172. Number of flakes of Kutau/Bao obsidian found in archaeological sites in Remote 0ceania increasingly distant from the Reef/Santa Cruz Islands. The quantity has not been standardised by excavation area/volume as this information is not available for all sites. Most sites yielding Kutau/Bao obsidian have been investigated in medium to large-scale investigations (e.g. SE-RF-2, Makue, Teouma, Naigani, Bourewa, Lakeba-Wakea, Nukuleka). Recent excavations at Nukuleka by David Burley (pers. comm.) found an obsidian flake that may be from the Kutau/Bao source.

a Lapita subsistence economy. Historical linguistics has developed a detailed model of intraarchipelagic colonisation that can be compared with archaeological data, but skeletal and genetic studies, although supporting a complex settlement history, are currently unable to determine the dispersal pattern (Pietrusewsky 1990; Visser 1994; Serjeantson and Gao 1995; Kelly 1996; van Dijk 1998).

\section{Dialect variation}

Linguistic studies suggest that the Central Pacific subgroup (CP) of Oceanic was a dialect chain that initially spanned the Fiji-Tonga region (Marck 2000; Kirch and Green 2001:56-61). During the first centuries of Lapita settlement, morphological and lexical innovations developed between central and western Fiji (Viti Levu and southwest Vanua Levu) and northeast Vanua Levu, the Lau Group and Tonga. The latter branch of CP was termed 'Tokalau Fijian-Polynesian' by Geraghty (1983), as 'tokalau' means 'northeast' in Fijian, and Pawley (n.d.) suggests that the 'Tokalau' innovations developed before permanent occupation of islands north of Tonga. When permanent settlement of Samoa and adjacent islands did take place at about 2700-2800 BP 
there was a further set of diagnostic innovations that defined Nuclear Polynesian. In Fiji, the affiliation of the Tokalau Fijian-Polynesian dialect subsequently changed, with the dialects of northeast Vanua Levu and the Lau Group resynthesising with the dialects of central and western Fiji, creating a 'Proto-Fijian' dialect chain over most of the Fiji Group.

Dating dialect-chain developments is notoriously difficult, but the archaeological record shows Lapita movement to the Lau Group-southern Tonga and then southern Tonga-Samoa within a short period between $2950 \mathrm{cal}$. BP and $2750 \mathrm{cal}$. BP. Each expansion (central and western Fiji to northeast Fiji-southern Tonga, and southern Tonga to Samoa and nearby islands) appears to have led to the development of significant language innovations in newly established settlement frontiers. The resynthesis of central and western Fijian with Tokalau Fijian-Polynesian must have occurred after Rotuman and Pre-Polynesian diverged from the CP dialect chain, and prior to the development of substantial inland populations on Viti Levu (Pawley and Sayaba 1971; Pawley 1999) in the period 2000-1000 BP. An age estimate of 2500-2000 BP for the 'Proto-Fijian' period appears reasonable, as it provides several centuries for the language innovations marking Tokalau Fijian-Polynesian and Nuclear Polynesian to develop.

The complicated sequence of language development in the Central Pacific and particularly in Fiji suggests that there may be evidence for an early material-culture divide between central and western Fiji and northeast Fiji-southern Tonga, which closed with language resynthesis across Fiji in the period 2500-2000 BP, before the dialect diversification documented by Geraghty (1983), shown in Figure 173.

\section{Archaeological data}

We now examine the archaeological evidence for Lapita colonisation of Fiji, particularly the ceramic record, as it is the most abundant and best described category of prehistoric material culture. Other types of information relevant to this issue are omitted due to space restrictions (see Chapters 4-10).

Lapita sites with stylistically early ceramics are found only on Viti Levu and nearby islands (Bourewa, Naigani, Yanuca, Natunuku and Naitabale). Intricate dentate stamping also occurs on a small number of sherds at Lakeba (site 101/7/196) (Best 2002:41), but no Lapita sites in the Yasawa Islands or in the Lau Group appear to be as early as those found on, or near to, Viti Levu. The apparent consolidation of early Lapita settlements on the large island of Viti Levu, followed by later movement to smaller landmasses, is consistent with incremental movement from the largest island in the archipelago, but it is a view that could, in part, stem from the small number and size of early Lapita sites relative to late-Lapita sites, which means that early sites will be harder to locate in archaeological survey, even on small islands. A similar pattern of expansion from a large island to small islands is proposed for Tonga, where the oldest Lapita site is found on Tongatapu (Burley and Dickinson 2001; Burley 2007), and in New Caledonia Lapita sites on the Grand Terre are older than those found on smaller offshore limestone islands like the Loyalty Group that appear to have been colonised one or two centuries later (Sand 1998).

The concentration of early Lapita groups on Viti Levu and a subsequent clinal pattern of movement through the Fiji Group suggested by decorated ceramics is not well attested in the radiocarbon dates. The oldest adequately dated sites in the early group are Bourewa on the southwest coast of Viti Levu, with an estimated range of 2950-3050 cal. BP, Naigani at 2800-2900 cal. BP, and Lakeba (site 196), at 2750-2950 cal. BP (NZ 4590). The remaining sites are not well dated. Yanuca has a potential age range of 2750-2950 cal. BP from a result on the shell of Batissa violcea (ANU-11414, Clark and Anderson 2001b), and Naitabale might be dated by Wk-11481 to 2850-3050 cal. BP, but other determinations from the site indicate an 


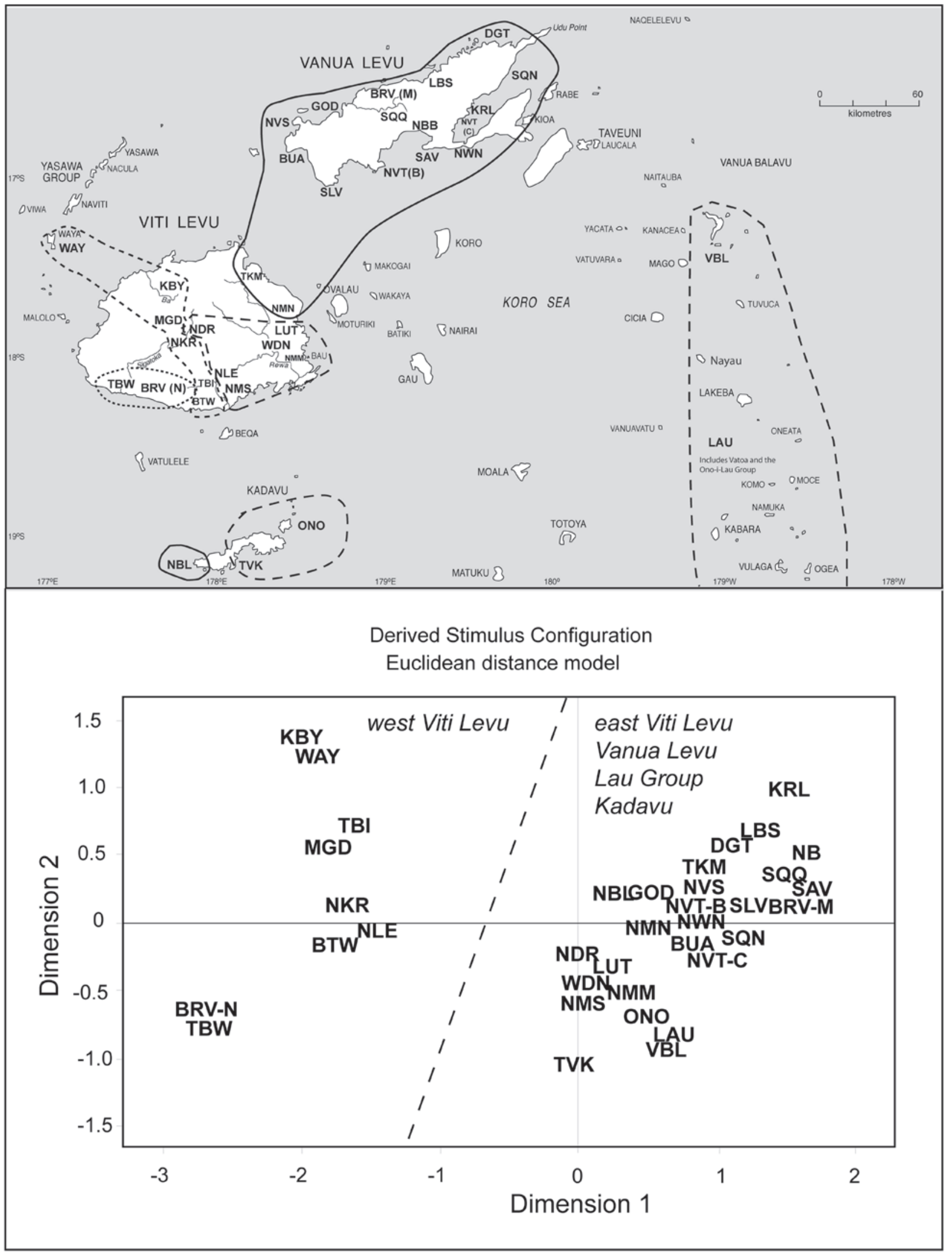

Figure 173. Map of Fiji (top) showing results of an MDS analysis of communalect association based on phonological innovations in 32 communalects recorded by Geraghty (1983:Table 16). MDS analysis of phonological innovations (bottom) divides the communalects of west Viti Levu from the communalects of east Viti Levu, Vanua Levu, Kadavu and the Lau Group, suggesting that the east Viti Levu division from west Viti Levu is of considerable antiquity and possibly dates to the post-Lapita period (see Pawley and Sayaba 1971). 
age of 2700-2850 cal. BP (Nunn et al. 2007). In contrast, several late-Lapita sites, including Sigatoka Level 1 (2450-2650 cal. BP) and Votua on Mago Island (2700-2800 cal. BP), are well dated (see Chapter 7).

The radiocarbon dates on their own are too few and have an age span that prohibits the detection of any clear pattern of archipelago movement, other than the observation that Viti Levu appears to have the earliest sites, bearing in mind the absence of archaeological work on Vanua Levu. Lapita pottery was made in Fiji for at least 400-500 years (cf. Anderson and Clark 1999), providing ample time for significant stylistic change in the ceramic corpus and the proliferation of Lapita settlements in the archipelago. With the discovery of Lapita and postLapita sites containing complete or nearly complete vessels, ceramicists will increasingly use information from the whole container to assess inter-site and intra-site relationships (see vessel data and analyses in Birk 1973; Sand et al. 1998; Burley 2005; Bedford 2006; Clark 2007; Clark and Wright 2007). But at the present time, it is necessary to investigate site relationships using a variety of ceramic data, including the percentage of vessels decorated, types of vessel form, and motif presence/absence. The frequency of dentate-stamped and incised motifs in an assemblage is an important source of information (Best 1984; Clark and Murray 2006), which is not yet available for the early sites of Bourewa and Naitabale.

\section{Ceramics: Percentage decorated}

The frequency of dentate-stamped and incised decoration in Fijian assemblages is highest at Natunuku, Yanuca and Naigani (ceramics from Bourewa are under analysis). Best (2002:Table 4) calculated a relative site age from the percentage of three early traits in ceramic assemblages: rouletting, flat-based dishes and carinations (calculated against the percentage of all dentatestamped and incised sherds in an assemblage). Taking the average of the three percentage values, the sites in order from oldest to youngest are Natunuku, Yanuca, Lakeba, Naigani and the TO-2 Nukuleka site in Tonga. Pottery from the Naitabale site was not able to be analysed in Best's 2002 study, but is considered earlier than that of Naigani (Best in Nunn et al. 2004b:218). A percentage comparison of ceramic decoration by Nunn et al. (2007:Table 3), from oldest to youngest, ordered the sites: Naigani, Natunuku, Yanuca, Nukuleka (Tonga), Haateiho (Tonga) and Naitabale. However, the $0.6 \%$ decorated percentage in the Naitabale assemblage is consistent with radiocarbon dates from the site that indicate the presence of a later and larger Lapita occupation (Best 2002:84; Nunn 2007; Nunn et al. 2007:Table 3). The Naigani values for dentate-stamping (33.0\%) and incised decoration (27.9\%) in the Nunn et al. (2007) study are incorrect according to Best (2002:84).

Rather than a spilt between Lapita groups in west Fiji and those of east Fiji (see Clark and Anderson 2001a), Best's percentage data suggest a relatively early dispersal through Fiji to the Lau Islands and Tonga, along with the possibility that Lapita groups were continuing to arrive on Viti Levu, as suggested from Kutau/Bao obsidian at Naigani, which also has an unusually high frequency of decorated sherds (dentate-stamped 24\%, incised 9.5\%, see Best 2002:84), similar to the Vatcha site in New Caledonia, which also contains Kutau/Bao obsidian (Sand and Sheppard 2003; Nunn et al. 2007:Table 3).

\section{Ceramics: Vessel form}

The amount of decoration in Fijian Lapita assemblages declines over time, as does the number of complex vessel forms. Fragmentation of pottery containers varies within and between sites, making an intersite comparison difficult, and for sites such as Naitabale and Bourewa the form of ceramic containers has yet to be published. Restricting ourselves to those assemblages where 
there is sufficient information to determine vessel form (Clark and Anderson 2001a:Table 2) reveals seven vessel categories (bowls, constricted orifice, jars, jars with large applied bands, jars with carinations/convex shoulders, wide-mouthed carinated jars/dishes, dishes with flaring rims and flat bases) in six sites (Yanuca, Natunuku, Lakeba (sites 196 and 197), Naigani, Sigatoka and Votua).

The relationship of assemblages based on vessel form is shown in Figure 174, and suggests that Yanuca and Natunuku are the oldest, followed by Naigani and Lakeba, and then the lateLapita assemblages of Sigatoka Level 1 and Votua. The site order is somewhat similar to that suggested by Best (2002), and the results also support the view that Lapita migration to Fiji from the west was still occurring at 2800-2900 cal. BP, some 50-150 years after initial colonisation if Bourewa is dated to 2950-3050 cal. BP.

\section{Ceramics: Motif presencelabsence}

There have been several attempts to code Lapita designs to enable inter-site and archipelago comparisons to track Lapita movement. In the case of Fijian ceramic assemblages, pioneering work by Mead and others attempted to investigate the design process and pattern-making 'rules' (Mead et al. 1973), while other researchers restrict themselves to creating design inventories (Anson 1983; Best 1984; Poulsen 1987; Chiu 2003). There are several problems with an inventory approach for Lapita decoration that varies markedly in the number, complexity and density of designs in early sites - especially those in the west of the distribution - compared with Lapita designs in Fiji-West Polynesia, which are fewer in number, simplified in pattern and executed in an open and sparse style. One of the most basic issues is that decoration in a few 'type assemblages' forms the majority of a design reference catalogue that may omit many of the designs present in other assemblages, even though some of these may be comparable to

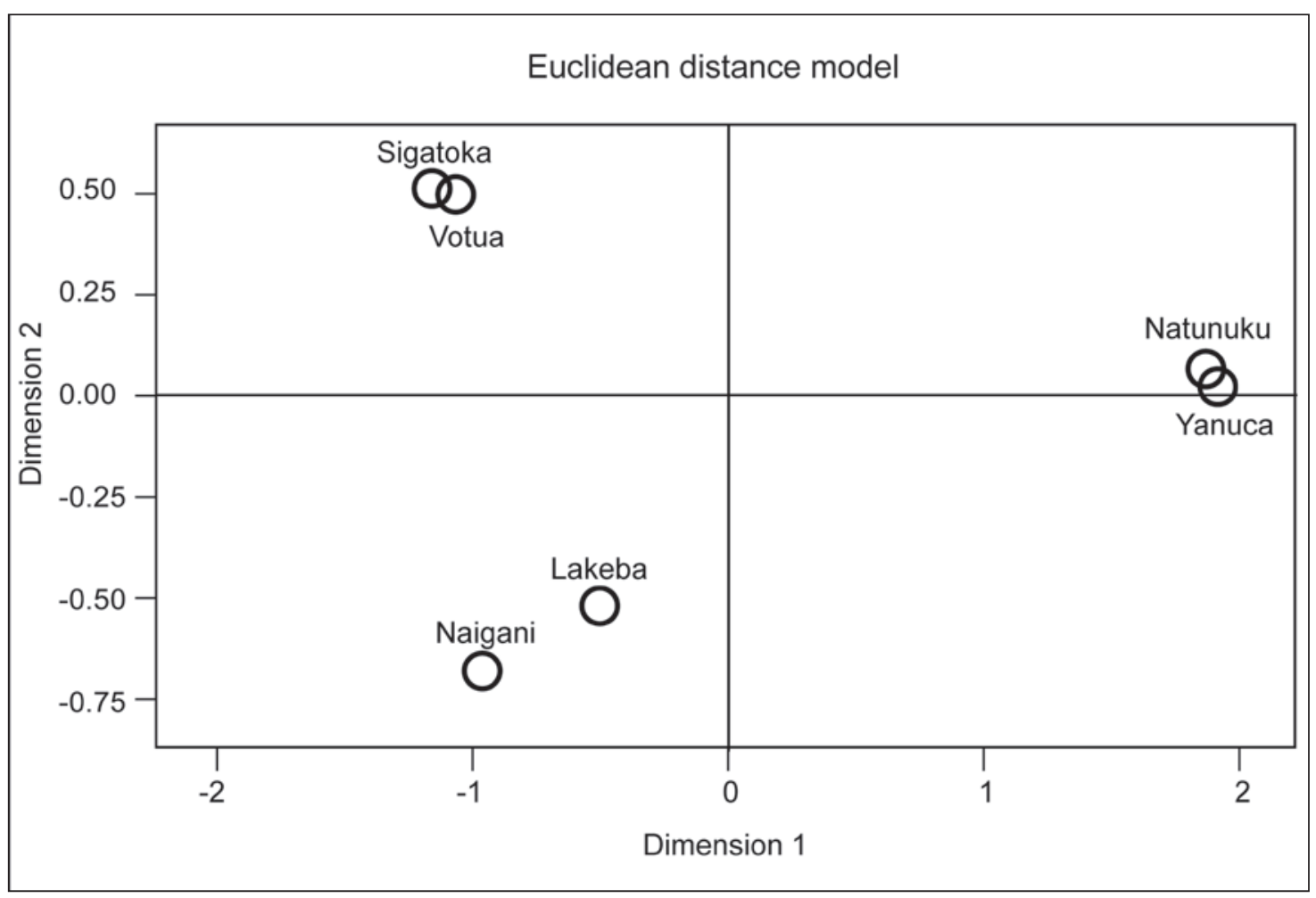

Figure 174. Lapita assemblage relationships from an MDS analysis of seven vessel form categories from six Lapita sites in Fiji (Yanuca, Natunuku, Sigatoka, Votua, Lakeba, Naigani). 
designs in an inventory. Several researchers have used Anson's (1983) motif catalogue to examine Lapita movements and inter-site relationships (Summerhayes 2001), and to describe Lapita assemblages (Bedford 2006), including those recently excavated in Fiji (Nunn et al. 2007), and the approach is followed here.

The presence/absence of motifs in five early Lapita sites in Fiji (Natunuku, Yanuca, Naigani, Naitabale and Lakeba (site 196 and 197)) was tabulated from published sources (Anson 1983; Kay 1984; Nunn et al. 2007). The simplified Lakeba motifs were recorded using a different system (Best 1984), but the majority could be assigned to motifs or motif variants listed by Anson (1983). To examine site relationships within Fiji, two motif outgroups were included in the analysis. The first was the SC-RF-2 motifs from the Reef/Santa Cruz Islands and the second was the Site 13 motifs from New Caledonia recorded by Anson (1983). The purpose of the outgroups was to illustrate the relative similarity/difference among Fijian assemblages by comparing them with assemblages from other island groups that should be dissimilar, particularly if Lapita expansion in Remote Oceania was predominantly incremental or clinal, which would have provided time for local ceramic development in each island group before movement to new island groups. Late-Lapita ceramics from Sigatoka and Votua were not included due to the small number of motifs/part motifs. These late assemblages are important, however, as they demonstrate that by $2700-2800$ cal. BP, the Lapita design system of Fiji had decomposed to a point where dentate-stamping of pottery vessels was rare, and in design terms, stylistically minimal.

Motifs from the seven Lapita assemblages were binary coded for presence/absence and analysed with MDS (squared Euclidean distance), and compared with HCL results using the squared Euclidean distance and simple matching coefficient, which produced the same results. Previous motif studies of Lapita site relationships have used the Jaccard coefficient index in which joint absences are excluded from consideration and equal weight is given to matches and nonmatches (Best 1984, 2002). However, as the Lapita design system declines, the number of joint absences will rapidly increase and this aspect of stylistic change should be included in an inter-site measurement. As a result, the simple matching coefficient, which measures the ratio of matches to the total number of values and gives equal weight to matches and nonmatches, was preferred.

The results of the MDS motif analysis are shown in Figure 175. As expected, the motifs in the Fijian assemblages group together, away from the motifs in the RF-2 site in the Reef/ Santa Cruz Islands and the Site 13 motifs in New Caledonia. Revised dating of the RF-2 site (Green et al. 2008) suggests it is similar in age or slightly younger than the oldest sites in Fiji (RF-2 age: 68\% CI 2825-2983, 2949-3145 and 95\% CI 2724-3062, 2878-3271). Sand (1997) has dated surviving components of Site 13 to about 3100-3000 cal. BP (WKO013A/B). Among the Fijian assemblages, those of Lakeba and Naitabale group together, with Naigani more distant. The HCL analysis suggests that the sites in order from oldest to youngest are: Yanuca, Natunuku, Naigani, Naitabale and Lakeba, which is similar to the site-age order in the vessel-form analysis. Natunuku and Yanuca are closest to the other Fijian assemblages, but are the most distant from the Reef/Santa Cruz and New Caledonia motif sets, even though they may well have a similar age. If Fiji was settled from Vanuatu, then Vanuatu motifs dating from 3000-2900 cal. BP should be similar to motifs from Yanuca and Natunuku, a hypothesis that can be examined from a comparison of the Bourewa motifs and new assemblages excavated from Vanuatu (e.g. Bedford 2006).

The similarity of the east Fiji Lakeba motifs to those from the Naitabale site close to Viti Levu could result from devolution of the Lapita design system or interaction between east Fiji and west Fiji. First, design decay may have removed the majority of complex dentate-stamped 


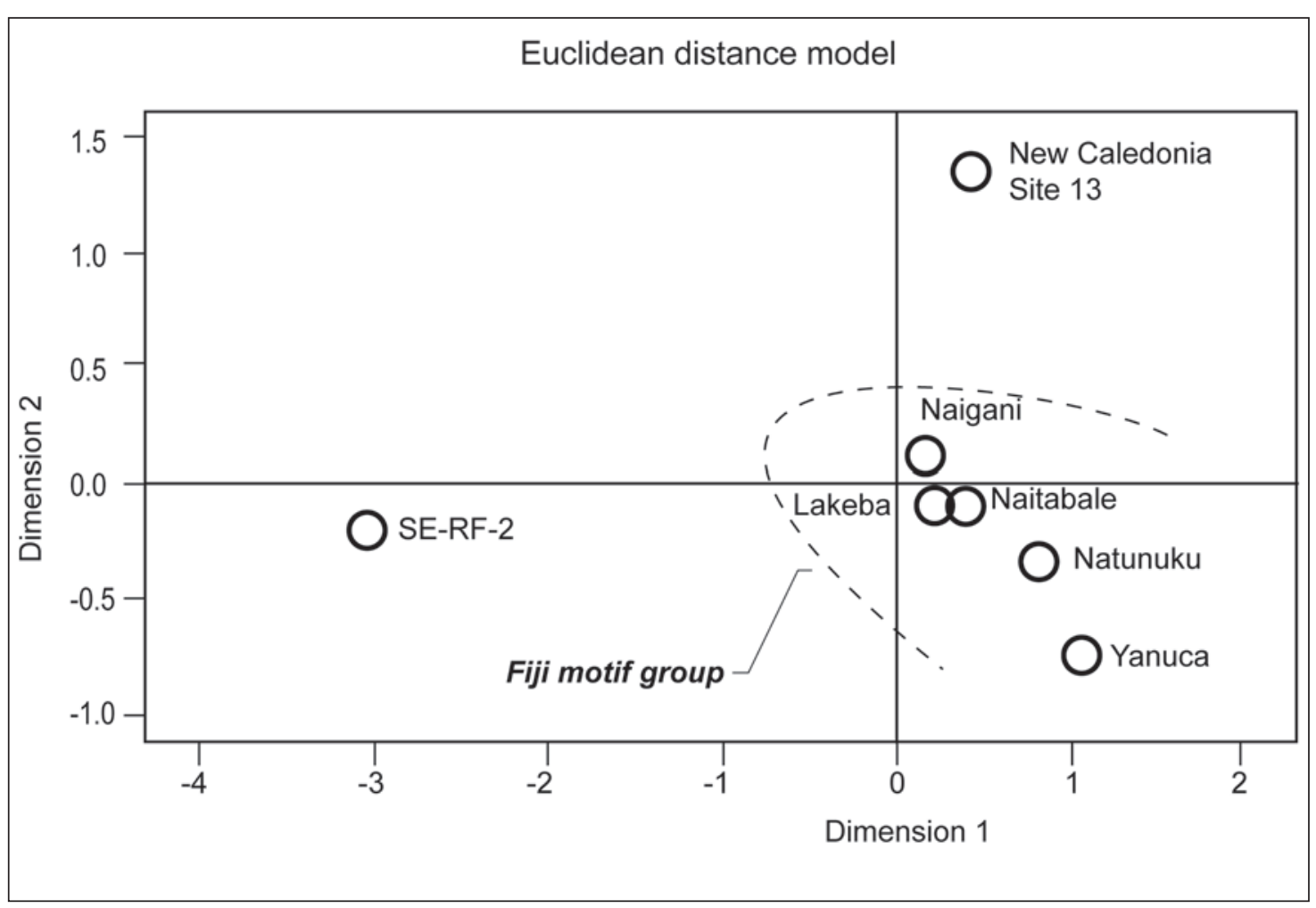

Figure 175. Lapita assemblage relationships from an MDS (squared Euclidean distance) analysis of motif presence/ absence (simple matching coefficient) from five Fijian sites (Yanuca, Natunuku, Naitabale, Lakeba, Naigani), SE-RF-2 (Reef/Santa Cruz) and Site 13 (New Caledonia).

and incised designs by about $2800 \mathrm{cal}$. BP, with the remainder consisting of the most frequently used designs in the decorative corpus. The stylistic association among decorated Lapita ceramics would increase through time, therefore, due to the similarity of the decay pathway, with assemblages from Naitabale and Lakeba towards the end of the sequence grouping together because of their late age. Given the number of motifs recorded from Naitabale (40), this idea is not well supported. An alternative is that Lapita groups in the west and east of Fiji were in frequent contact with one another and the motif presence/absence reflects ongoing interaction across the archipelago at the same time as language innovations were accumulating in westcentral Fiji and east Fiji-Tonga. The latter would mean that language innovations were largely decoupled from changes to ceramic material culture. Lapita and post-Lapita ceramics and material culture from intermediate locations such as southern Lau, located between Tonga and west Fiji, would clarify the alternatives (see Clark 2009).

\section{Lapita sites: Size and characteristics}

Turning to the size of sites as a proxy for Lapita group/community size, the earliest components at Naitabale, Naigani, Bourewa and Lakeba are small and appear to have been around only 1000 and 2500 sq. m (Best 1984; Nunn 2007). The Yanuca rock shelter and Natunuku sites were also likely to have occupied a small area, although erosion and development means their size cannot be determined. The late-Lapita Level 1 component at the Sigatoka Sand Dunes is also in this range (although Burley (2003) suggests the Level 1 deposit is not an occupation), as is the Votua site on Mago, and the sites on Qoqo Island and Beqa Island, among others (Clark 2000; Clark et al. 2001; Jones et al. 2004; Nunn et al. 2006; Cochrane et al. 2007). The anomaly is Lakeba, 
where Wakea (site 196) is estimated to cover 15,000 sq. m of the coastal flat (Best 2002), and the site could well be considerably larger, based on the surface distribution of dentate-stamped sherds and the inclusion of the nearby Qaranipuqa (site 197) rock shelter. Elsewhere on Lakeba, sites larger than the Wakea Lapita site are rare and only occur in the late prehistoric period when large fortifications and community settlements were developed (Best 1984:Table 2.1).

The large size of the Wakea site could result from the concentration of migrants in 'gateway' communities (Hirth 1978), which acted as fixed points for exploration, dispersal and population consolidation in frontier environments. Several studies emphasise the significance of known points in new landscapes in migration (Lee 1996; Moore 2001), and whatever the actual number of Lapita people arriving in Fiji, the population density during colonisation must have been low relative to archipelago size and land area. A dendritic coastal settlement pattern of a few relatively large sites in strategic locations across the archipelago would allow for efficient exploration of the hinterland and would provide a staging post for further expansion by a numerically small and mobile population.

Lapita sites in Fiji are located in diverse environments and situations different from the restricted criteria suggested by Lepofsky's (1988) innovative catchment analysis. In southern Lau, Lapita and post-Lapita ceramic sites are located in leeward settings on palaeoshorelines around shallow embayments that would have provided canoe shelter, but more importantly, access to concentrations of Anadara and Gafrarium bivalves (Clark 2009). On Mago Island, the Votua site is behind a headland in a small cove containing mangroves and dense concentrations of bivalves close to an intermittent stream. Proximity to broad fringing reefs and estuary environments appears to have been the most important consideration for locating the prehistoric communities at Sigatoka and Natunuku, as well as Bourewa, Naitabale, Qoqo and Rove, reported by Nunn and colleagues (Nunn et al. 2004a, 2005, 2006; Kumar et al. 2004), and may have been critical to the establishment of the Wakea site on Lakeba, and the Kulu Bay and Ugaga sites in the Beqa lagoon. Neither a reef-break 'canoe passage' nor a permanent fresh water source appear to have been necessary factors in Lapita site placement compared with the presence of a significant fringing reef and sheltered embayments with abundant gregarious bivalves. Fresh water may have been obtained at some sites, such as Wakea and several others in the Lau Group, from intertidal springs debouching from the limestone substrate, while on Ugaga Island in the Beqa lagoon, fresh water must have been carried to the island.

No inland sites with complex dentate-stamped decoration have yet been found in Fiji. There is a late-Lapita shell-impressed arc on a rim from the Qaranioso II shelter several kilometres inland (Anderson et al. 2001), and simple dentate markings were found on a sherd at another inland location on Viti Levu (Kumar and Nunn 2003). Best (2002:22) found inland settlement on Lakeba only occurred in Period II at ca. $2500 \mathrm{cal}$. BP, consistent with a late-Lapita inland presence on Viti Levu. Excavations at Tatuba Cave some $45 \mathrm{~km}$ from the mouth of the Sigatoka River indicate use of the interior by 1700-2000 cal. BP (Field 2004), similar to the age of several EPF cave/rock shelters (see Chapter 7). The archaeology of island interiors is an important and under-researched topic in Pacific prehistory, although human activity and occupation in areas distant from coastal resources in Fiji has been examined in several studies (Parry 1987; Kuhlken and Crosby 1999), particularly the development of fortified sites (Field 2004, 2005) in relation to climate change in the past 750 years (Kumar et al. 2006; Nunn 2007; Nunn et al. 2007).

The potential effects of climate change on the development of human societies in Fiji requires fine-grained archaeological and palaeoecological studies of human activity in a variety of inland landscapes (i.e. valley floors, ridge lines, rock shelters, riparian zones, agricultural systems, fortifications) before as well as after 1000 BP. Furthermore, it is vitally important, 
in making those connections, to be able to rule out the obvious alternative that movement into new habitats and changes in subsistence and settlement patterns, plus increasing evidence of defensive structures or warfare, are more clearly associated with population growth, as the late activation of the Sigatoka Sand Dunes, probably through increased rates of erosion and sedimentation, might represent (Anderson et al. 2006b).

Current site locations point to a Lapita presence in Fiji that was tethered in the main to coastal settlements, but which involved forays to the interior to collect resources such as finegrained rocks for adze manufacture, for the hunting of endemic fauna and for the collection of economic food and craft plants. The dispersal of Lapita groups through terrestrial landscapes was clearly substantially slower than dispersal across water gaps to islands, suggesting that coastal resources and environments were basic to migration subsistence, an issue we examine further below.

\section{Subsistence economies}

The issue of subsistence strategies involved in Lapita migration is contentious in large part because the subsistence mode is connected to theories of Neolithic migration, especially the hypothesis of a cohesive spread of farming, language and people (and their genes) over large parts of the world (Diamond and Bellwood 2003; Bellwood 2005). For Lapita migration, the central issue is whether initial dispersal carried a suite of domesticated fauna and flora with it, or whether transported biotas arrived in a piecemeal fashion perhaps over several centuries (Groube 1971; Clark and Anderson 2001a; Davidson and Leach 2001; Burley 2007). What is not in dispute is that, as on other oceanic islands, human arrival in Fiji had a significant impact on native fauna, particularly the avifauna, but also on endemic reptiles like the extinct giant iguana (Lapitiguana impensa), terrestrial crocodilian (Volia athollandersoni) and giant ground frog (Platymantis megabotoniviti) (Chapter 3).

Skeletal remains from introduced animals (pig, dog, chicken) found in Fijian Lapita sites were critically evaluated in Chapter 10, with only the chicken and the non-food commensal Pacific rat (Rattus exulans) and spiny rat (Rattus praetor) able to be confirmed as Lapita-era introductions in the Lau Islands. Pig remains are present in early Lapita sites in the Bismarck Archipelago, as well as in northern and central Vanuatu, but they have not been found in Lapita sites in New Caledonia, southern Vanuatu or Tonga (see Chapter 10), and reports of dog remains at Naigani and Yanuca in Fiji similarly need to be confirmed. On Lakeba, remains of the pig and dog do not appear in the sequence until about 1000 BP (Best 1984:197, 555).

Adventive land snails from early levels of Yanuca have also been used to infer early horticulture, with Lamellaxis gracilis and Gatsrocopta pediculus potentially transported on plants, although not necessarily cultigens (Hunt 1981; Clark and Anderson 2001a:83), and the basal sediments of Yanuca have been redeposited (Hunt 1980:39; Clark and Anderson 2001b). Direct evidence for transported crops has been identified at Bourewa where Horrocks and Nunn (2007) report microfossil remains of Colocasia esculenta (taro) and Dioscoria esculenta (lesser yam).

The first point to note about the presence of taro and yam at Bourewa is that the sediment sample from Pit X20 at 55-63 cm depth post-dates two radiocarbon determinations on marine shell, with a range of $2440-2710 \mathrm{cal}$. BP, indicating a late-Lapita age for the sediment sample. Ploughing of the upper $40 \mathrm{~cm}$ and the presence of four post-Lapita burials in Pit X20, mostly below the plough zone, suggests that the sediment sample need not be associated with the Lapita component of the site. The other sediment sample yielding identified microfossils of taro and lesser yam was collected from Pit X25 at $134 \mathrm{~cm}$ depth. A ${ }^{14} \mathrm{C}$ determination on Conus sp. shell from $140 \mathrm{~cm}$ depth at the base of a marine-shell midden deposit (Wk-17544) has an age of 
3250-3450 cal. BP, which is older than all other determinations from the site, and it may date naturally deposited beach shell (Nunn 2007:172). It is uncertain whether the sediment dates to the early Lapita occupation or later.

Horrocks and Nunn (2007:746) place use of taro and yam at Bourewa in 'mid-Lapita' rather than late-Lapita times, as is suggested by the radiocarbon results for Pit X20, and they propose that the impetus for horticulture was sea-level fall that exposed dry land suitable for root-crop planting around the former tidal inlet. However, if the X25 sample from the base of the cultural deposit dates to ca. 3000 cal. BP it would demonstrate the early arrival of horticulture in Fiji before sea-level fall when Bourewa was a low elongate sand spit/barrier island that would have been unfavourable for growing root crops. In a recent paper, Nunn (2009) says that cultivars were not introduced to Bourewa until $2800 \mathrm{cal}$. BP, but the reason for rejecting the association between the early radiocarbon age (Wk-17544) and sediment sample yielding remains of taro and lesser yam in Pit X25 is not discussed.

At other Lapita sites in Fiji, the environmental location appears to have been orientated towards marine and wild terrestrial resources rather than optimal horticultural zones. For instance, sandy beach flats backed by steep limestone/volcanic slopes backed by cliffs is inimical to horticulture (e.g. Kulu Bay, Wakea, Votua), and narrow coastal sand flats/spits fronting fringing reefs also have limited horticultural potential (e.g. Bourewa, Votua, Ugaga, Qoqo Island, Naitabale).

There is another issue in Horrocks and Nunn (2007) - the identification of starch. Hardy et al. (2009) point to basic problems in starch identification, noting that the current 'best fit' morphological method is unreliable for species identification. As Horrocks and Nunn used a reference collection composed exclusively of material from plants cultivated in Pacific prehistory, there is a possibility that their identifications of cultivated plants are merely by default and that a much wider range of potential source material would provide different results.

Recognising the difficulty of identifying evidence of agriculture, especially of plant remains in early Lapita sites, the available subsistence data still supports Best's (1984:650-653, 2002:23-25) argument for a primary focus on wild resources from the oldest layers of the Lakeba (site 197) rock shelter that show an emphasis on turtle and birds, including the hunting of now-extinct species (Chapter 10; and see Field et al. 2009). In Tonga, Burley (1998:35) found the location of Lapita sites on Tongatapu and Ha'apai suggested that access to wild resources was more important than proximity to horticultural land. However, in Vava'u, Lapita sites were positioned close to inland swales suitable for wet taro production (Burley 2007), and similar small-scale topographical variation could be hidden beneath sediments at Natunuku, Bourewa, Sigatoka and Kulu Bay. Alternatively, Lapita-era gardens may have been located some distance from coastal settlements and reconstruction of Lapita site palaeogeography, particularly the location of soils of high horticulture potential in addition to back-beach swales, could be used to identify locations where traces of Lapita horticulture could be sought.

The initial subsistence mode in Fiji and the change in the inventory of domesticated plants and animals during the Lapita era needs to be established by directly dating and recovering remains from secure Lapita contexts, and employing robust analytical methods to securely identify economic plant remains. We believe that some cultigens were probably introduced during the Lapita era, but nonetheless suggest the default position should be 'absent until demonstrated', as archaeological proof of prehistoric subsistence is essential for evaluating variability in prehistoric migrations (e.g. Kirch 1997:203-212; Bellwood 2005). 


\section{Post-Lapita transformations}

A Lapita period in Fiji lasting 400-500 years that involved relatively small mobile populations which settled the coastal margins of islands and utilised inland resources cannot be envisaged as a homogeneous culture/society, as the early linguistic dialect divisions and the results of motif analysis attest (Figure 175). However, by 2500-2000 cal. BP community mobility had declined relative to the Lapita period when inter-archipelagic movement through the Central Pacific was relatively common, and when the settlement hierarchy appears to have involved strategically positioned sites like Wakea on Lakeba. Such sites were located along voyaging routes and on occupation frontiers that were connected to a range of smaller sites in the hinterland. Some contact between island groups persisted post-Lapita, but the locus of group/community interaction shifted once population growth and population distribution led to backfilling of empty/sparsely inhabited territory so that inter-group encounters for economic materials and social activity such as spouse exchange no longer required long-distance voyaging and the concentration of migrants in gateway communities.

A focus by post-Lapita groups on specific island environments is suggested by the reduction in long-distance intra-archipelagic imports, the reduced scale of intra-archipelago movement, the predominance of local production modes seen in the manufacture of post-Lapita ceramics (Chapter 13) and the local geochemistry of stone adzes/flakes (Chapter 15). The re-analysis of obsidian from post-Lapita levels on Lakeba shows that it is not from northern Vanuatu as originally thought, which means there is currently a total absence of geochemical evidence for any inter-archipelago contact with Fiji during the period 2500-1000 BP. This result can be attributed in part to a focus on colonisation sites of the Lapita era, on the one hand, and the highly visible late-period fortifications/structures, on the other.

Even so, the similarity in the evidence for early Lapita mobility (3000-2500 BP) and that of late prehistoric social interaction (1000-200 BP) indicates that two very different events early colonisation/migration and the late prehistoric development of complex societies - created archaeological signatures of extensive social interaction that are somewhat similar. The signatures of long-distance interaction are only superficially related, however, because the movement of non-local material products during migration/colonisation relates to the volume and direction of the migration stream, and the social value of items, like obsidian, in it, whereas in stratified chiefly societies non-local goods are frequently prestige items involving craft specialisation and the return of items to socio-political centres, as is likely to be the case with adzes manufactured on Tutuila in Samoa that were transported widely in the Pacific (Best et al. 1992; Kirch and Green 2001; Clark 2002).

The resynthesis of central and western Fijian with Tokalau Fijian dialects, and its spilt with Tongic is estimated to have taken place during the early part of the post-Lapita period (Pawley 1999 , n.d.). If dialect resynthesis was influenced by the infilling of archipelago environments, then human impact on island landscapes should be evident through the expansion of settlements in a larger number of locations and increased anthropogenic activity on islands. On smaller islands, these events may well have occurred earlier than on large islands due to the increase in population size in relation to finite resources, particularly productive arable land (see Kirch 1984a). However, palaeoecological records from the Lau Group, the Yasayasa Moala Group and Viti Levu document increasing environmental impact on large and on small islands after 2500 cal. BP (see Chapter 4).

On Lakeba (59 sq. km), the Waitabu Swamp core indicates that burning and erosion were underway on the southeast coast before 2000 BP, but increased massively during the period 
from 1900 to $1750 \mathrm{cal}$. BP (Latham et al. 1983). The main phase of vegetation clearance and erosion on Yacata Island (8.5 sq. km) dates to 2530-1100 BP (Clark and Hope 2001), similar to Totoya (28 sq. km), where palaeoecological cores suggest the 'onset of substantial burning and sedimentation by the end of Period I.2 [2500-2000 BP]', with a second round of substantial vegetation disturbance around 1700 BP (J. Clark and Cole 1997:152). On Viti Levu (10,531 sq. $\mathrm{km}$ ), forest clearance and erosion in the highlands near the source of the Sigatoka River created a levee in which $6 \mathrm{~m}$ of sedge peat developed within the past 2100 years (Hope et al. 1999; Anderson et al. 2006b:151), while the poorly dated Bonatoa Bog in the Rewa Delta also suggests the decline of lowland forests after about 2500 BP (Chapter 4; Hope et al. 1999: Figure 3).

An increased focus on island landscapes in the early post-Lapita period relative to the multiisland and predominantly near-coast focus of Lapita times must have involved new settlement strategies and an increasing concern with ownership and access to land and economic resources that involved negotiation and competition among groups. Archaeological data for this is currently inadequate, although it might be represented in central and southern Lau by the presence of Period 2 sites (ca. 2500-2100 BP) in every part of the landscape, including the highest hilltops (Best 2002:21). Best (1984:562) considered the coincidence in the archaeological record of cannibalism and use of interior hilltops after 2500 BP as being 'diagnostic of stress, and presumably internal strife'.

On Viti Levu during the middle of the first millennium AD settlements appear in new locations that also suggest an increasing concern with control of land and its defence. Navatu 17A was positioned on the flanks of a steep volcanic plug and in the Sigatoka Valley easily defended hilltops termed 'territorial fortifications' came into existence (Field 2004). At the same time, open coastal sites existed at Sigatoka on the stable Level 2 palaeosol formed during a period of low ENSO activity from 2400 to 1600 cal. BP (Moy et al. 2002; Burley 2005; Anderson et al. 2006b). Human remains from the Sigatoka Sand Dune and Lakeba post-Lapita sites, however, do not have injuries consistent with conflict (Visser 1994), although cannibalism may be an early post-Lapita trait (Best 1984:Appendix O). Status differentiation in the post-Lapita period is shown by the burial treatment at Sigatoka (Best 1989; Visser 1994:170-186), and by the concentration of ornate and complex double-spouted vessels from the lower levels of Navatu 17A associated with potentially high-status food items such as cannibalised human remains and turtle bone (Chapter 10). Economic specialisation is also likely at this time from the large flatbased ceramic pans recorded from Viti Levu and the Yasawas (Lambert 1971; Clark and SoroviVunidilo 1999:10), which may have been used to produce salt from evaporation of seawater (Burley 2005). Salt was an important late-prehistoric exchange commodity between coastal and inland groups (Williams 1985 [1858]:94) that may have been traded inland during the postLapita period.

Dialect variation on Viti Levu increased with settlement of the interior and separation of east and west populations, by the topographical barrier of the Nadrau Plateau, which can be archaeologically dated to about 1500-2000 BP (Chapters 4-6). The Eastern dialect group covered the largest area, encompassing most of the Fiji Group (eastern Viti Levu, Vanua Levu, Lau Group), while the Western dialect was restricted to western Viti Levu, the Yasawas and Vatulele (see Pawley (1981) and Pawley and Ross (1995) for general models of in situ language diversification in Melanesia). Geraghty's (1983) study of dialect variation examined phonological innovations in 32 communalects, which preserves the main east Viti Levu-west Viti Levu division (Figure 173) and shows the emergence of additional dialect variability in Fiji. Phonological innovations provide a relatively coarse measure of language relationships, as is the 
case with northeast Viti Levu grouping with Vanua Levu, but northeast Viti Levu differs in its lexicon and grammar from Vanua Levu (Geraghty 1983). The main point to keep in mind is that the process of dialect variation in the post-Lapita period does not disclose any evidence that language variability was influenced by migration/contact with Vanuatu/New Caledonia, and that local processes of communalect development were also dominant in the late-prehistoric era, notwithstanding a significant Tongan influence in parts of Fiji.

In the first and second millennium $\mathrm{AD}$ dialect divergence can be attributed to geographic proximity, topographic barriers and influence of social groups/chiefdoms. For instance, Geraghty (1983) suggests the existence of a southeast Viti Levu (Koro Sea) prestige dialect area, implying that the Verata-Bau-Rewa seat of political power in the 19th century had been influential long before. Thus, while language change and social transformation in the Lapita era of Fiji-West Polynesia can be viewed as the outcome of migrant arrival and interaction in frontier environments, in post-Lapita times a new and complicated set of local relationships developed within Fiji that controlled community and social development. One outcome of this with high archaeological visibility was change in post-Lapita ceramics, but inter-group competition, settlement of the interior and other previously under-used landscapes, accompanied by subsistence adaptations and economic specialisation, are hallmarks of the post-Lapita period that require much more archaeological investigation (see Hunt 1986).

In the West Pacific, studies have shown that genetic differences between inland and coastal populations are amplified by island size and the ruggedness of island topography, which combine to increase rates of genetic drift (Friedlander et al. 2007). While Fiji was settled much more recently, it is likely that similar factors contributed to the cultural and physical differences noted between inland and coastal groups in Fiji in the 19th century that fuelled a theory that Fiji had an early 'Melanesian' population stratum and a more recent 'Polynesian' population stratum (Clark 2003). Linguistic studies demonstrate that landscape topography on Viti Levu led to dialect variation (Pawley and Sabah 1971; Geraghty 1983) and it is reasonable to suggest that variation in genetic composition and cultural traits also increased in the post-Lapita period. Longdistance interaction/contact with Vanuatu/New Caledonia has been proposed as an important factor influencing the course of post-Lapita Fiji, but there is currently little archaeological and linguistic support for it, and the effects of local processes on the development of human diversity in Fiji need to be taken up in future research.

\section{References}

Addison, D.J. and A.E. Morrison In press. The Lapita settlement of Samoa: Is a continuous occupation model appropriate? In: Proceedings of the VII International Conference on Easter Island and the Pacific Islands: Migration, identity, and cultural heritage, Gotland, Sweden.

Allen, J. and O'Connell, J.F. 2008. Getting from Sunda to Sahul. In: Clark, G.R., Leach, F. and O'Connor, S. (eds), Islands of inquiry: Colonisation, seafaring and the archaeology of maritime landscapes, pp. 31-46. Terra Australis 29. Canberra, ANU E Press.

Anderson, A.J. 2001. Mobility models of Lapita migration. In: Clark, G.R., Anderson, A.J. and Vunidilo, T. (eds), The archaeology of Lapita dispersal in Oceania, pp.15-23. Terra Australis 17, Pandanus Press, Canberra.

Anderson, A.J. 2002. Faunal collapse, landscape change and settlement history in Remote Oceania. World Archaeology 33: 375-390. 
Anderson, A.J. 2003. Initial dispersal in Remote Oceania: Pattern and explanation. In: Sand, C. (ed), Pacific archaeology: Assessments and prospects. Les cahiers de l'archéologie en Nouvelle-Calédonie 15, pp. 71-84. Départment Archéologie, Service des Musées et du Patrimoine de NouvelleCalédonie, Noumea.

Anderson, A.J. 2008a. Traditionalism, interaction and long-distance seafaring in Polynesia. Journal of Island and Coastal Archaeology 3: 240-250, 268-270.

Anderson, A.J. 2008b. The rat and the octopus: Initial human colonization and the prehistoric introduction of domestic animals to Remote Oceania. Biological Invasions DOI 10.1007/s10530008-9403-2.

Anderson, A. and Clark, G. 1999. The age of Lapita settlement in Fiji. Archaeology in Oceania 34: 31-39.

Anderson, A., Clark, G. and Worthy, T. 2000. An inland Lapita site in Fiji. Journal of the Polynesian Society 109(3): 311-316.

Anderson, A., Bedford, S., Clark, G., Lilley, I., Sand, C., Summerhayes, G. and Torrence, R. 2001. A list of Lapita sites containing dentate-stamped pottery. In: Clark, G.R., Anderson, A.J. and Vunidilo, T. (eds), The archaeology of Lapita dispersal in Oceania, pp. 1-13. Terra Australis 17, Pandanus Press, Canberra.

Anderson, A.J. and White, J.P. (eds) 2001. The Prehistoric Archaeology of Norfolk Island, Southwest Pacific. Supplement 27, Records of the Australian Museum.

Anderson, A.J. and Sinoto, Y.H. 2002. New radiocarbon ages of colonization sites in East Polynesia. Asian Perspectives 41: 242-257.

Anderson, A.J., Chappell, J., Gagan, M., and Grove, R. 2006a. Prehistoric maritime migration in the Pacific Islands: An hypothesis of ENSO forcing. The Holocene 16: 1-6.

Anderson, A., Roberts, R., Dickinson, W., Clark, G., Burley, D., De Biran, A., Hope, G. and Nunn, P. 2006b. Times of sand: sedimentary history and archaeology at the Sigatoka Dunes, Fiji. Geoarchaeology 21: 131-154.

Anson, D. 1983. Lapita pottery of the Bismarck Archipelago and its affinities. Unpublished PhD thesis, University of Sydney.

Athens, J.S., Dega, M.F. and Ward, J. 2004. Austronesian colonisation of the Mariana Islands: The palaeoenvironmental evidence. Bulletin of the Indo-Pacific Prehistory Association 24: 21-30.

Bedford, S. 2006. Pieces of the Vanuatu Puzzle: Archaeology of the North, South and Centre. Terra Australis 23. Canberra: Pandanus Books, The Australian National University.

Bellwood, P. 2005. Coastal south China, Taiwan, and the prehistory of the Austronesians. In: Chey, C-Y and Pan, J-G (eds), The Archaeology of Southeast Coastal Islands of China Conference, pp. 1-22, Executive Yuan, Council for Cultural Affairs, Taiwan.

Best, S. 1984. Lakeba: The prehistory of a Fijian island. Unpublished PhD thesis, Department of Anthropology, University of Auckland.

Best, S. 1989. The Sigatoka dune burials (Site VL 16/1). Unpublished report to the Fiji Museum, Suva.

Best, S. 2002. Lapita: A view from the east. New Zealand Archaeological Association Monographs 24, Auckland.

Best, S.B., Sheppard, P., Green, R.C. and Parker, R. 1992. Necromancing the stone: Archaeologists and adzes in American Samoa. Journal of the Polynesian Society 101: 45-85.

Birks, L. 1973. Archaeological excavations at Sigatoka dune site, Fiji. Bulletin of the Fiji Museum No.1.

Burley, D. 1998. Tongan archaeology and the Tongan past, 2850-150 B.P. Journal of World Prehistory 12(3): 337-392.

Burley, D.V. 2003. Dynamic landscapes and episodic occupations: Archaeological interpretation and implications in the prehistory of the Sigatoka Sand Dunes. In: Sand, C. (ed), Pacific archaeology: Assessments and prospects, pp. 307-315. Les Cahiers de l' Archéologie en Nouvelle-Calédonie Number 15, New Caledonia. 
Burley, D. 2005. Mid-sequence archaeology at the Sigatoka Sand Dunes with interpretive implications for Fijian and Oceanic culture history. Asian Perspectives 44(2): 320-348.

Burley, D.V. 2007. In search of Lapita and Polynesian Plainware settlements in Vava'u, Kingdom of Tonga. In Bedford, S., Sand, C. and Connaughton, S.P. (eds), Oceanic Explorations: Lapita and Western Pacific settlement, pp. 187-198. Terra Australis 26. ANU E Press, Australian National University.

Burley, D.V. and Dickinson, W.R. 2001. Origin and significance of a founding settlement in Polynesia. Proceedings of the National Academy of Sciences 98: 11829-11831.

Burley, D.V., Dickinson, W.R., Barton, A. and Shutler, R. Jr. 2001. Lapita on the periphery: New data on old problems in the Kingdom of Tonga. Archaeology in Oceania 36: 89-104.

Callaghan, R. and Fitzpatrick, S.M. 2009. Examining prehistoric migration patterns in the Palauan Archipelago: A computer simulated analysis of drift voyaging. Asian Perspectives 47: 28-44.

Carson, M.T. 2008. Refining earliest settlement in Remote Oceania: Renewed archaeological investigation at Unai Bapot, Saipan. Journal of Island and Coastal Archaeology 3: 115-139.

Chappell, J. 2005. Geographic changes of coastal lowlands in the Papuan past. In: Pawley, A., Attenborough, R., Golson, J. and Hide, R. (eds), Papuan pasts: Cultural, linguistic and biological histories of Papuan-speaking peoples, pp. 289-328. Pacific Linguistics, Canberra.

Chiu, S. 2003. Social and economic meanings of Lapita pottery: A New Caledonia case. In: Sand, C. (ed), Pacific archaeology: Assessments and prospects. Les cahiers de l'archéologie en NouvelleCalédonie 15, pp. 159-182. Départment Archéologie, Service des Musées et du Patrimoine de Nouvelle-Calédonie, Noumea.

Clark, G. 2000. Post-Lapita Fiji: Cultural transformation in the mid-sequence. Unpublished PhD thesis, Australian National University.

Clark, G. 2002. Adzes of interaction: Samoan basalt artefacts in Fiji. In: Bedford, S., Sand, C. and Burley, D. (eds.), Fifty years in the field, pp. 227-238. New Zealand Archaeological Association Monograph.

Clark, G. 2003. Shards of meaning: Archaeology and the Melanesia-Polynesia distinction. Journal of Pacific History 38(2): 197-213.

Clark, G. 2004. Radiocarbon dates for the Ulong site in Palau and implications for western Micronesian prehistory. Archaeology in Oceania 39: 26-33.

Clark, G. 2005. A 3000-year culture sequence from Palau, western Micronesia. Asian Perspectives 44: 349-380.

Clark. G. 2007. Standardization, specialization and Lapita ceramics. In: Bedford, S., Sand, C. and Connaughton, S.P. (eds.), Oceanic explorations: Lapita and Western Pacific settlement, pp. 289-299. Terra Australis 26. ANU E Press, Australian National University.

Clark, G. 2009. Early ceramic sites in southern Lau, Fiji. Archaeology in New Zealand 62: 81-89.

Clark, G. and Sorovi-Vunidilo, T. 1999. Double-spouted vessels from Fiji. Domodomo 11(2): 6-11.

Clark, G. and Hope, G. 2001. Archaeological and palaeoenvironmental investigations on Yacata Island, northern Lau, Fiji. Domodomo 13(2): 29-47.

Clark, G. and Anderson, A. 2001a. The pattern of Lapita settlement in Fiji. Archaeology in Oceania 36: 77-88.

Clark, G. and Anderson, A. 2001b. The age of the Yanuca Lapita site, Viti Levu, Fiji. New Zealand Journal of Archaeology 22: 15-30.

Clark, G., Anderson, A. and Matararaba, S. 2001. The Lapita site at Votua, northern Lau Islands, Fiji. Archaeology in Oceania 36: 134-145.

Clark, G. and Murray T. 2006. Decay characteristics of the eastern Lapita design system. Archaeology in Oceania 41: 107-117.

Clark, G., Anderson, A. and Wright, D. 2006. Human colonization of the Palau Islands, western Micronesia. Journal of Island and Coastal Archaeology 1: 215-232. 
Clark, G. and Wright, D. 2007. Reading Pacific pots. In: Anderson, A., Green, K. and Leach, F. (eds), Vastly Ingenious: The archaeology of Pacific material culture in honour of Janet M. Davidson, pp. 173-190. University of Otago Press, Dunedin.

Clark, G. and Bedford, S. 2008. Friction zones in Lapita colonisation. In: Clark, G.R., Leach, F. and O'Connor, S. (eds), Islands of inquiry: Colonisation, seafaring and the archaeology of maritime landscapes, pp. 59-73. Terra Australis 29. Canberra, ANU E Press.

Clark, J.T. 1996. Samoan prehistory in review. In: Davidson, J.M., Irwin, G., Leach, B.F., Pawley, A. and Brown, D. (eds), Oceanic culture history: essays in honour of Roger Green, pp. 445-460. New Zealand Journal of Archaeology Special Publication.

Clark, J.T. and Cole, T. 1997. Environmental change and human prehistory in the Central Pacific: Archaeological and palynological investigations on Totoya Island, Fiji. Unpublished report to the Fiji Museum, Suva.

Cochrane, E.E., Matararaba, S. and Nakoro, E. 2007. Lapita and later archaeology of the Malolo and Mamanuca Islands, Fiji. Journal of Island and Coastal Archaeology 2: 245-250.

Cochrane, E.E. 2008. Migration and cultural transmission: Investigating human movement as an explanation for Fijian ceramic change. In: O'Brian, M.J. (ed), Cultural transmission and archaeology: Issues and case studies, pp. 132-145. Society for American Archaeology, The SAA Press, Washington, DC.

Conte, E. and Anderson, A.J. 2003. Radiocarbon ages for two sites on Ua Huka, Marquesas. Asian Perspectives 42: 155-160.

Craib, J. 1999. Colonisation of the Mariana Islands: New evidence and implications for human movements in the western Pacific. In: Galipaud, J-C. and Lilley, I. (eds), The Pacific from 5000 to 2000 BP. Colonisation and transformations, pp. 477-486. IRD Editions, Paris.

Davidson, J.M. and Leach. B.F. 2001. The strandlooper concept and economic naivete. In: Clark, G.R., Anderson, A.J. and Vunidilo, T. (eds), The archaeology of Lapita dispersal in Oceania, pp. 115-123. Terra Australis 17, Pandanus Press, Canberra.

DeFant, D.G. 2008. Early human burials from the Naton beach site, Tumon Bay, Island of Guam, Mariana Islands. Journal of Island and Coastal Archaeology 3: 149-153.

Diamond, J. and Bellwood, P. 2003. Farmers and their languages: The first expansions. Science 300: 597-603.

Dickinson, W.R. 2006. Temper sands in prehistoric Oceanian pottery: Geotectonics, sedimentology, petrography, provenance. Geological Society of America Special Papers 406. The Geological Society of America, Boulder, Colorado.

Dickinson, W.R. and Green, R.C. 1998. Geoarchaeological context of Holocene subsidence at the Ferry Berth site. Mulifanua, Upolu, Western Samoa, Geoarchaeology 13: 239-263.

Dickinson, W.R. and Athens, J.S. 2007. Holocene paleoshoreline and paleoenvironmental history of Palau: Implications for human settlement. Journal of Island and Coastal Archaeology 2: 175-196.

Dodson, J.R. and Intoh. M. 1999. Prehistory and palaeoecology of Yap, Federated States of Micronesia. Quaternary International 59: 17-26.

Donohue, M. and Denham, T. 2008. The language of Lapita: Vanuatu and an early Papuan presence in the Pacific. Oceanic Linguistics 47: 433-444.

Felgate, M.W. and Dickinson, W.R. 2001. Late-Lapita and Post-Lapita pottery transfers: Evidence from intertidal-zone sites of Roviana Lagoon, Western Province, Solomon Islands. In: Jones, M. and Sheppard, P.J. (eds), Proceedings of the 2001 Australasian Archaeometry Conference, pp. 105-122. Research Papers in Anthropology and Linguistics, Number 5, Auckland.

Felgate, M. 2007. Leap-frogging or Limping? Recent evidence from the Lapita littoral fringe, New Georgia, Solomon Islands. In: Bedford, S., Sand, C. and Connaughton, S.P. (eds), Oceanic Explorations: Lapita and Western Pacific settlement, pp. 123-140. Terra Australis 26. ANU E Press, Australian National University.

Field, J.S. 2004. Environmental and climatic considerations: A hypothesis for conflict and the 
emergence of social complexity in Fijian prehistory. Journal of Anthropological Archaeology 23: 79-99.

Field, J.S. 2005. Land tenure, competition and ecology in Fijian prehistory. Antiquity 79: 586-600. Field, J.S., Cochrane, E.E. and Greenlee, D.M. 2009. Dietary change in Fijian prehistory: Isotopic analyses of human and animal skeletal material. Journal of Archaeological Science 36: 1547-1556.

Friedlaender, J.S., Friedlaender, F.R., Hodgson, J.A., Stoltz, M., Koki, G., Horvat, G., Zhadanov, S., Schurr, T.G. and Merriwether, D.A. 2007. Melanesian mtDNA complexity. PLoS One 2: 1-13.

Frimagacci, J.P. and Siorat, B.Vienne. 1983. Inventaire et fouille des sites archeologiques et ethnohistoriques de l'ile d'Uvea. Centre de Noumea Sciences Humaines, ORSTOM, Nouvelle-Caledonie.

Geraghty, P.A. 1983. The history of the Fijian languages. Oceanic Linguistics Special Publication No. 19. University of Hawaii Press, Honolulu.

Gongora, J., Rawlence, N.J., Mobeg V.A., Jianlin, H., Alcalde, J.A., Matus, J.T., Hanotte, O., Moran, C., Austin, J.J., Ulm, S., Anderson, A.J., Larson, G., and Cooper, A. 2008. Reply to Storey et al.: More DNA and dating studies needed for ancient Arenal-1 chickens. Proceedings of the National Academy of Sciences of the USA 105: E100.

Green, R.C. 1991. Near and Remote Oceania - disestablishing 'Melanesia' in culture history. In: Pawley, A.K. (ed), Man and a half: essays in honour of Ralph Bulmer. pp. 491-502. Polynesian Society, Auckland.

Green, R.C. 2002. A retrospective view of settlement pattern studies in Samoa. In: Ladefoged, T. and Graves, M. (eds), Pacific Landscapes Archaeological Approaches, pp. 125-152. California: The Easter Island Foundation, Bearsville Press.

Green, R.C. 2003. The Lapita horizon and traditions - signature for one set of Oceanic migrations. In: Sand, C. (ed.), Pacific archaeology: Assessments and prospects. Les cahiers de l'archéologie en Nouvelle-Calédonie 15, pp. 95-120. Départment Archéologie, Service des Musées et du Patrimoine de Nouvelle-Calédonie, Noumea.

Green, R.C. and Kirch, P.V. 1997. Lapita exchange systems and their Polynesian transformations: seeking explanatory models. In: Weisler, M.I. (ed), Prehistoric long-distance interaction in Oceania: an interdisciplinary approach. pp. 19-37. New Zealand Archaeological Association Monograph 21.

Green, R.C. and Weisler, M.I. 2002. The Mangarevan sequence and dating of the geographic expansion into southeast Polynesia. Asian Perspectives 41: 213-241.

Green, R.C., Jones, M. and Sheppard, P. 2008. The reconstructed environment and absolute dating of SE-SZ-8 Lapita site on Nendo, Santa Cruz, Solomon Islands. Archaeology in Oceania 43: 49-61.

Groube, L.M. 1971. Tonga, Lapita pottery, and Polynesian origins. Journal of the Polynesian Society 80: 278-316.

Groube, L.M. 1996. The geometry of the dead. In: Davidson, J.M., Irwin, G., Leach, B.F., Pawley, A. and Brown, D. (eds), Oceanic culture history: essays in honour of Roger Green. pp. 133-165. New Zealand Journal of Archaeology Special Publication.

Hardy, K., Blakeney, T., Copeland, L., Kirkham, J., Wrangham, R., and Collins, M. 2009. Starch granules, dental calculus and new perspectives on ancient diet. Journal of Archaeological Science, 36: $248-255$.

Hirth, K.G. 1978. Interregional trade and the formation of gateway communities. American Antiquity 43(1): 35-45.

Hope, G., O'Dea, D. and Southern, W. 1999. Holocene vegetation histories in the Western Pacific alternative records of human impact. In: Lilley, I. and Galipaud, J-C. (eds), The Pacific from 5000 to 2000 BP. Colonisation and transformations, pp. 387-404. IRD Editions, Paris.

Horrocks, M. and Nunn, P.D. 2007. Evidence for introduced taro (Colocasia esculenta) and lesser yam (Dioscorea esculenta) in Lapita-era (3050-2500 cal. yr BP) deposits from Bourewa, southwest Viti Levu Island, Fiji. Journal of Archaeological Science 34: 739-748.

Hunt, T.L. 1980. Toward Fiji's past; archaeological research on southwestern Viti Levu. Unpublished MA thesis, University of Auckland. 
Hunt, T.L. 1981. New evidence for horticulture in Fiji. Journal of the Polynesian Society 90: 259-269.

Hunt, T.L. 1986. Conceptual and substantive issues in Fijian prehistory. In: Kirch, P.V. (ed),

Archaeological approaches to evolution and transformation, pp. 20-32. Cambridge University Press, Cambridge.

Hunt, T.L. and Lipo, C.P. 2008. Evidence for a shorter chronology on Rapa Nui (Easter Island). Journal of Island and Coastal Archaeology 3: 140-148.

Irwin, G. 1992. The Prehistoric exploration and colonisation of the Pacific.: Cambridge University Press, Cambridge.

Irwin, G. 2008. Pacific seascapes, canoe performance, and a review of Lapita voyaging with regard to theories of migration. Asian Perspectives 47: 12-27.

Jones O'Day, S., O'Day, P. and Steadman, D.W. 2004. Defining the Lau context: Recent findings on Nayau, Lau Islands, Fiji. New Zealand Journal of Archaeology 25: 31-56.

Kay, R. 1984. Analysis of archaeological material from Naigani. Unpublished MA thesis, University of Auckland.

Kelly, K.M. 1996. The end of the trail: The genetic basis for deriving the Polynesian peoples from Austronesian speaking palaeopopulations of Melanesian Near Oceania. In: Davidson, J.M., Irwin, G., Leach, B.F., Pawley, A. and Brown, D. (eds), Oceanic culture history: essays in honour of Roger Green, pp. 355-364. New Zealand Journal of Archaeology Special Publication.

Kirch, P.V. 1984a. The evolution of the Polynesian chiefdoms. Cambridge University Press, Cambridge, New York, Port Chester, Melbourne, Sydney.

Kirch, P.V. 1984b. The Polynesian outliers: Continuity, change, and replacement. Journal of Pacific History 19: 224-238.

Kirch, P.V. 1988. Niuatoputapu: The prehistory of a Polynesian chiefdom. Thomas Burke Memorial Washington State Museum Monograph No. 5. The Burke Museum, Seattle.

Kirch, P.V. 1997. The Lapita Peoples. Ancestors of the Oceanic world. Blackwell Publishers, Cambridge and Oxford.

Kirch, P.V. and Green, R.C. 2001. Hawaiki, Ancestral Polynesia. An essay in historical anthropology. Cambridge University Press, United Kingdom.

Kuhlken, R. and Crosby, A. 1999. Agricultural terracing at Nakauvadra, Viti Levu: A late prehistoric irrigated agrosystem in Fiji. Asian Perspectives 38: 62-89.

Kumar, R. and Nunn, P.D. 2003. Inland and coastal Lapita settlement on Viti Levu Island, Fiji: New Data. Domodomo 16: 15-20.

Kumar, R., Nunn, P.D., Katayama, K., Oda, H., Matararaba, S. and Osborne, T. 2004. The earliestknown humans in Fiji and their pottery: The first dates from the 2002 excavations at Naitabale (Nartururuku), Moturiki Island. South Pacific Journal of Natural Science 22: 15-21.

Kumar, R., Nunn, P.D., Field, J. and De Biran, A. 2006. Human response to climate change around AD 1300: A case study of the Sigatoka Valley, Viti Levu Island, Fiji. Quaternary International 151: 133-143.

Lambert, R. 1971. Botanical identification of impressions on archaeological potsherds from Sigatoka. Final Report No. 3. Records of the Fiji Museum 1: 124-148.

Larson, G., and 31 additional authors. 2007. Phylogeny and ancient DNA of Sus provides insights into Neolithic expansion in Island Southeast Asia and Oceania. Proceedings of the National Academy of Sciences, USA, 104: 4834-4839.

Latham, M., Hughes, P.J., Hope, G. and Brookfield, M. 1983. Sedimentation in the swamps of Lakeba and its implications for erosion and human occupation of the island. In: Latham, M. and Brookfield, H.C. (eds), The eastern Fiji Islands. A study of the natural environment, its use and man's influence on its evolution, pp. 103-119. General Report No. 3 of the UNESCO/UNFPA Project, ORSTOM, Paris.

Lee, E.S. 1996 [1965]. A theory of migration. In: Cohen, R. (ed), Theories of migration, pp. 14-57. Edward Elgar, United Kingdom. 
Lepofsky, D. 1988. The environmental context of Lapita settlement location. In: Kirch, P.V. and Hunt, T.L. (eds), Archaeology of the Lapita culture complex: A critical review. pp. 33-47. Thomas Burke Memorial Washington State Museum Research Report No. 5. Burke Museum, Seattle.

Lilley, I. 2002. Lapita and Type Y pottery in the KLK site, Siassi, Papua New Guinea. In: Bedford, S., Burley, D. and Sand, C. (eds), Fifty years in the field. Papers in honour of Richard Shutler, pp. 79-90. New Zealand Archaeological Association, Auckland.

Lilley, I. 2008. Flights of fancy: Fractal geometry, the Lapita dispersal and punctuated colonisation in the Pacific. In: Clark, G.R., Leach, F. and O'Connor, S. (eds), Islands of inquiry: Colonisation, seafaring and the archaeology of maritime landscapes, pp. 75-86. Terra Australis 29. ANU E Press, Canberra

Liston, J. 2005. An assessment of radiocarbon dates from Palau, western Micronesia. Radiocarbon 47: 295-354.

Marck, J. 2000. Topics in Polynesian language and culture history. Pacific Linguistics, Canberra.

Mead, S., Birks, L., Birks, H. and Shaw, E. 1973. The Lapita pottery style of Fiji and its associations. Journal of the Polynesian Society Memoir 38: 1-98.

Moore, J.H. 2001. Evaluating five models of colonization. American Anthropologist 103: 395-408.

Moy, C.M., Seltzer, G.O., Rodbell, D.T. and Anderson, D.M. 2002. Variability of El Nino/Southern Oscillation activity at millennial time scales during the Holocene epoch. Nature 420: 162-165.

Nunn, P.D. 2007. Echoes from a distance: Research into the Lapita occupation of the Rove Peninsula, southwest Viti Levu, Fiji. In: Bedford, S., Sand, C. and Connaughton, S.P. (eds), Oceanic Explorations: Lapita and Western Pacific settlement, pp. 163-176. Terra Australis 26. ANU E Press, Australian National University.

Nunn, P.D. 2009. Geographical influences on settlment-location choices by initial colonizers: A case study of the Fiji Islands. Journal of the Institute of Australian Geographers 47(3): 306-319.

Nunn, P.D., Matararaba, S., Ishimura, T., Kumar, R. and Nakoro, E. 2004a. Reconstructing the Lapita-era geography of Northern Fiji: A newly discovered Lapita site on Yadua Island and its implications. New Zealand Journal of Archaeology 26: 41-55.

Nunn, P.D., Kumar, R., Matararaba, S., Ishimura, T., Seeto, J., Rayawa, S., Kuruyawa, S., Nasila, A., Oloni, B., Ram, A.R., Saunivalu, P., Sing, P and Tegu, E. 2004b. Early Lapita settlement site at Bourewa, southwest Viti Levu Island, Fiji. Archaeology in Oceania 39: 139-143.

Nunn, P.D., Pepe, C., Matararaba, S., Kumar, R., Sing, P., Nakoro, E., Gwilliam, M., Heorake, T., Kuilanisautabu, L., Nakoro, E., Narayan, L., Pastorizo, M.A., Robinson, S., Saunivalu, P. and Tamani, F. 2005. Human occupations of caves of the Rove Peninsula, southwest Viti Levu Island, Fiji. South Pacific Journal of Natural Science 23: 16-23.

Nunn, P.D., Matararaba, S., Kumar, R., Pene, C., Yuen, L., Pastorizo, M.A. 2006. Lapita on an island in the mangroves? The earliest human occupation at Qoqo Island, Southwest Viti Levu, Fiji. Archaeology in New Zealand 49: 205-212.

Nunn, P.D., Hunter-Anderson, R., Carson, M.T., Thomas, F., Ulm, S. and Rowland, M.J. 2007. Times of plenty, times of less: Last-millennium societal disruption in the Pacific Basin. Human Ecology 35(4): 385-401.

Parry, J. 1987. The Sigatoka valley - pathways into prehistory. Fiji Museum Bulletin No. 9. The Fiji Museum, Suva.

Pawley, A. 1981. Melanesian diversity and Polynesian homogeneity: A unified explanation for language. In: Hollyman, J. and A. Pawley (eds), Studies in Pacific languages and cultures: Essays in honour of Bruce Biggs, pp. 269-309. Linguistic Society of New Zealand, Auckland.

Pawley, A. 1999. Chasing rainbows: implications for the rapid dispersal of Austronesian languages for subgrouping and reconstruction. In: Zeitoun, E. and Jenkuei Li, P. (eds), Selected papers from the eighth international conference on Austronesian linguistics. Symposium Series of the Institute of Linguistics (Preparatory Office), Academia Sinica, Number 1, Taiwan.

Pawley, A. 2007. The origins of early Lapita culture: The testimony of historical linguistics. In: 
Bedford, S., Sand, C. and Connaughton, S.P. (eds), Oceanic explorations: Lapita and Western Pacific settlement, pp. 17-49. Terra Australis 26. ANU E Press, Australian National University.

Pawley, A. n.d. Polynesian paradoxes: Subgroups, wave models and the dialect geography of Proto Polynesian. Draft paper for the Eleventh International Conference on Austronesian Linguistics (11.ical), 22-26 June 2009, Aussois, France.

Pawley, A. and Sayaba, T. 1971. Fijian dialect divisions: eastern and western Fijian. Journal of the Polynesian Society 80: 405-436.

Pawley, A. and Ross, M. 1995. The prehistory of the Oceanic languages; a current view. In: Bellwood, P., Fox, J.J. and Tryon, D. (eds), The Austronesians. pp. 39-74. Department of Anthropology, Research School of Pacific and Asian Studies, Australian National University.

Pietrusewsky, M. 1990. Lapita-associated skeletons from Watom Island, Papua New Guinea, and the origins of the Polynesians. Asian Perspectives 28(1): 83-89.

Poulsen, J. 1987. Early Tongan Prehistory. (2 volumes). Terra Australis 12. Department of Prehistory, Research School of Pacific Studies, Australian National University.

Reepmeyer, C and Clark, G. 2009. Post-colonisation interaction between Vanuatu and Fiji reconsidered: The reanalysis of obsidian from Lakeba Island, Fiji. Archaeometry.

Reepmeyer, C., Spriggs, M., Bedford, S. and Ambrose, A. In press. Provenance and technology of lithic artefacts from the Teouma Lapita site, Vanuatu. Asian Perspectives.

Reith, T.M., Morrison, A.E. and Addison, D.J. 2008. The temporal and spatial patterning of the initial settlement of Samoa. Journal of Island and Coastal Archaeology 3: 214-239.

Sand, C. 1990. the ceramic chronology of Futuna and Alofi: An overview. In: Spriggs, M. (ed), Lapita design, form and composition. pp. 123-133. Occasional Papers in Prehistory, No. 20, Department of Prehistory, Australian National University.

Sand, C. 1996. Archaeological research on Uvea Island, Western Polynesia. New Zealand Journal of Archaeology 18: 91-123.

Sand, C. 1997. The chronology of Lapita ware in New Caledonia. Antiquity 71: 539-547.

Sand, C. 1998. Recent archaeological research in the Loyalty Islands of New Caledonia. Asian Perspectives 37(2): 194-223.

Sand, C. 2001. Evolutions in the Lapita Cultural Complex: A view from the Southern Lapita Province. Archaeology in Oceania 36: 65-76.

Sand, C., Coote, K., Bole, J. and Outecho, A. 1998. A pottery pit at locality WKO013A, Lapita (New Caledonia). Archaeology in Oceania 33: 37-43.

Sand, C. and Sheppard, P. 2003. Long distance prehistoric obsidian imports in New Caledonia: Characteristics and meaning. Earth and Planetary Sciences 331: 235-243.

Serjeantson, S.W. and Gao, X. 1995. Homo sapiens is an evolving species: origins of the Austronesians. In: Bellwood, P., Fox, J.J. and Tryon, D. (eds), The Austronesians. pp. 165-176. Department of Anthropology, Research School of Pacific and Asian Studies, Australian National University.

Sheppard, P. 2003. Lapita lithics: Trade/exchange and technology. A view from the Reefs/Santa Cruz. Archaeology in Oceania 28: 121-137.

Sheppard, P. and Walter, R. 2006. A revised model of Solomon Islands culture history. Journal of the Polynesian Society 115: 47-76.

Specht, J. 2002. Obsidian, colonising and exchange. In: Bedford, S., Sand, C. and Burley, D. (eds), Fifty years in the field, pp. 37-49. New Zealand Archaeological Association Monograph.

Specht, J. 2007. Small islands in the big picture: The formative period of Lapita in the Bismarck Archipelago. In: Bedford, S., Sand, C. and Connaughton, S.P. (eds), Oceanic explorations: Lapita and Western Pacific settlement, pp. 51-70. Terra Australis 26. ANU E Press, Australian National University.

Spriggs, M. 1991. Nissan: The island in the middle. In: Allen, J. and Gosden, C. (eds), Report of the Lapita homeland project, pp. 222-243. Department of Prehistory, Research School of Pacific and Asian Studies, The Australian National University. 
Spriggs, M. 1995. The Lapita culture and Austronesian prehistory in Oceania. In: Bellwood, P., Fox, J.J. and Tryon, D. (eds), The Austronesians, pp. 112-133. Department of Anthropology, Research School of Pacific and Asian Studies, Australian National University.

Spriggs, M. 1997. The Island Melanesians. Blackwell Publishers Ltd, Oxford and Massachusetts.

Storey, A.A., Ramirez, J.M., Quiroz, D., Burley, D.V., Addison, D.J., Walter, R., Anderson, A.J., Hunt, T.L., Athens, J.S., Huynen, L. and Matisoo-Smith, E.A. 2007. Radiocarbon and DNA evidence for a pre-Columbian introduction of Polynesian chickens to Chile. Proceedings of the National Academy of Sciences of the USA 104: 10335-10339.

Summerhayes, G. 2001. Far Western, Western, and Eastern Lapita: A re-evaluation. Asian Perspectives 39(1-2): 109-118.

Summerhayes, G. 2004. The nature of prehistoric obsidian importation to Anir and the development of a 3,000 year old regional picture of obsidian exchange within the Bismarck Archipelago, Papua New Guinea. Records of the Australian Museum, Supplement 29: 145-156.

Szabo, K. and Summerhayes, G. 2002. Worked shell artefacts - new data from early Lapita. In: Bedford, S., Sand, C. and Burley, D. (eds), Fifty years in the field, pp. 91-100. New Zealand Archaeological Association Monograph.

Torrence, R. and Swadling, P. 2008. Social networks and the spread of Lapita. Antiquity 82: 600-616.

Torrence, R. and Doelman, T. 2007. Problems of scale: Evaluating the effects of volcanic disasters on cultural change in the Willaumez Peninsula, Papua New Guinea. In: Gratten, J. and Torrence, R. (eds), Living under the shadow: Cultural impacts of volcanic eruptions, pp. 42-66. Walnut Creek (CA), Left Coast Press.

Van Dijk, N. 1998. The Melanesians: An osteological study of their biological relationships within the Pacific. Unpublished PhD thesis, Australian National University.

Visser, E.P. 1994. The prehistoric people from Sigatoka: An analysis of skeletal and dental traits as evidence of adaptation. Unpublished PhD thesis, University of Otago, New Zealand.

Walter, R. and Anderson, A. 2002. The archaeology of Niue Island West Polynesia. Bishop Museum Bulletin in Anthropology 10. Bishop Museum Press, Honolulu.

Weisler, M.I. 1994. The settlement of remote Polynesia: New evidence from Henderson Island. Journal of Field Archaeology 21: 83-102.

Wickler, S. 2001. The prehistory of Buka: A stepping stone island in the northern Solomons. Terra Australis 16. Department of Archaeology and Natural History and Centre for Archaeological Research, The Australian National University.

Williams, T. 1985 [1858]. Fiji and the Fijians. The islands and their inhabitants. Fiji Museum, Suva.

Wilmshurst, J.M., Anderson, A., Higham, T.F.G. and Worthy, T. 2008. Dating the late prehistoric dispersal of Polynesians to New Zealand using the commensal Pacific rat. Proceedings of the National Academy of Sciences of the USA 105: 7676-7680. 
terra australis 31 